Boston University School of Law Scholarly Commons at Boston University School of Law

Faculty Scholarship

2003

\title{
Limits of the Classic Method: Positive Action in the European Union After the New Equality Directives
}

Daniela Caruso

Boston Univeristy School of Law

Follow this and additional works at: https://scholarship.law.bu.edu/faculty_scholarship

Part of the International Law Commons

\section{Recommended Citation}

Daniela Caruso, Limits of the Classic Method: Positive Action in the European Union After the New Equality Directives, 44 Harvard International Law Journal 331 (2003).

Available at: https://scholarship.law.bu.edu/faculty_scholarship/556 


\title{
BOSTON UNIVERSITY SCHOOL OF LAW
}

Working Paper Series, Public LaW \& Legal Theory

Working Paper No. 03-21

\section{Limits of THE Classic Method: Positive ACTION IN THE EUROPEAN UNION AFTER THE NEW EQUALITY DIRECTIVES}

\author{
DANIELA CARUSO
}

This paper can be downloaded without charge at:

The Boston University School of Law Working Paper Series Index: http://www.bu.edu/law/faculty/papers

The Social Science Research Network Electronic Paper Collection: $\underline{\text { http://papers.ssrn.com/abstract }=437202}$ 
44 Harvard International Law Journal 331

Summer, 2003

Article

LIMITS OF THE CLASSIC METHOD: POSITIVE ACTION IN THE EUROPEAN UNION
AFTER THE NEW EQUALITY DIRECTIVES

Daniela Caruso[FNa1]

Copyright (c) 2003 by President and Fellows of Harvard College; Daniela Caruso

I. INTRODUCTION

Affirmative action is once more the subject of heated discussion in the United States. Its legitimacy and merits are currently being revisited, and the participation of the Bush administration in the debate on race and equality has dramatically raised the visibility of yet other forms of affirmative action currently under scrutiny before the U.S. Supreme Court. [FN1] Meanwhile its lesser-known European relative, positive action, is experiencing, without much fanfare, a significant breakthrough in E.U. law. [FN2]

Positive action shares the logic of affirmative action. Both allow for preferential treatment of certain groups to make up for historical wrongs or traditional discrimination against them. However, in European circles, positive action is perceived as much more in tune with the principle of individual equality than its American counterpart. [FN3] In E.U. jargon, affirmative action is often used as a disparaging label to refer to a wide range of practices, including "hard" measures of intervention, designed to reach fixed quotas of minority representation in education and the workforce. Positive action, arguably, does not go that far because it consists of "soft" measures only. These measures avoid explicit quotas and preserve meritocracy. Arguably, they can be more easily defended as consonant with equality principles. It is commonly argued that, through such policies, European governments only help marginalized groups to enter the game, promising them a fair chance but no certain victory. As illustrated in this Article, the distinction between positive and affirmative action is difficult to maintain in practice and does not rest on firm theoretical grounds. However, the contrast is very popular in E.U. equality discourse, and allows for the survival of group-oriented redistributive policies under the label of positive action even in circles dominated by traditional equality rhetoric. [FN4]

Positive action's newfound salience in E.U. policies and governance lies in a recent and dramatic expansion of its scope. Until recently, the European Court of Justice (ECJ, or "the Court") could only address positive action policies concerning gender inequality. Recent treaty reforms, however, have added race, ethnicity, and religion as meaningful categories of identity within the scope of the E.C. Treaty. [FN5] Two E.C. directives currently being implemented allow member states to enact positive action measures in favor of racial, ethnic, and religious groups. [FN6] As a consequence, the jurisdiction of the EC] may now extend far enough to include review of such measures. [FN7]

The reform is a welcome step forward in the Union's pursuit of a healthier society. It signals legislative awareness of serious disharmonies due to the diversity of peoples on European soil. The acknowledgment of positive action as a permissible (though not mandated) tool of social engineering against the range of discriminatory practices is also welcome, and likely to weather the arguments of formal equality advocates. Yet the reform carries a non-obvious but fundamental drawback. The future development of positive action in favor of ethnic, racial, or religious groups is unambiguously linked to its gender-based origins. The positive action clauses of the new directives are 
modeled upon earlier provisions meant to redress sex discrimination. In all likelihood, the ECJ will interpret such terms along the lines of its previous scrutiny of gender programs. [FN8] This is, however, a chapter of E.U. history that should not be written.

A close analysis of the ECJ's decisions on positive action in favor of women casts serious doubt on the wisdom of extending that court's equality paradigm to matters of race, ethnicity, or religion. While written in the reassuringly nuanced language of proportionality, these decisions impose strict limits upon the member states' abilities to devise appropriate anti- discrimination measures according to local needs and statebased perceptions of social justice. Anchored as it is to a rigidly individualistic conception of rights, the Court lacks both conceptual and institutional tools to embrace complex issues of collective justice in diverse societies. [FN9]

Against the specter of this judicial development, this Article advocates a policy of restraint in the supranational scrutiny of positive action cases. The multifarious socioeconomic and cultural problems posed by the coexistence of multiple identities within the European constituency cannot be solved by means of uniform, E.U.-wide solutions. Nor can supranational scrutiny of positive action, based as it is on rights and centralized enforcement, do justice to the diverse legal and political sensibilities of national and subnational decision- makers. Positive action is a form of wealth redistribution, to be placed along a continuum of fiscal, economic, and social measures still within the sovereign control of member states, and not adequately captured by the equality paradigm so far applied by the ECJ. The Court should continue to ensure, through its individual rights jurisprudence, the protection of minorities against negative discrimination, but it should allow for broader state autonomy in the experimentation of positive-discrimination formulae designed to benefit marginalized groups. Positive action plans enacted by member states are now broadly endorsed by the new directives, and are therefore presumptively legitimate. Such plans should only be subject to the scrutiny of national courts, which are better equipped than the ECJ to determine a balance of equal rights and redistributive policies according to local context, culture, and welfare philosophy.

An E.U.-wide coordination of states' policies meant to combat the social exclusion of minorities should be achieved, when necessary, through alternative forms of European governance involving incentive measures and non- binding guidelines.

This argument develops through four analytical steps. Part II articulates a critique of the ECJ's positive action case law, based on the Court's over- reliance on the prescriptive power of its equality paradigm, and on the uncertain boundary between states and Community competencies in matters of social legislation. [FN10] Part III highlights the coexistence, in the law of the Union, of a strong commitment to individual rights on the one hand, and numerous recognitions of identity-based collective claims on the other. Affirmative action, in both soft and hard modes, can be conceived of as one among many existing forms of allocation of resources in favor of identity- defined groups, legitimized by the political consensus of the relevant constituency, rather than as an exceptional derogation from the canon of individual equality and blind justice. Part IV provides state-based examples of ongoing identitybased redistribution, sharing the essence, if not the form, of affirmative action. These illustrations show how measures targeting ethnic or religious groups for redistributive purposes are not uncommon in both national and supranational policies. They are natural adaptations of welfare state policies to the diversity of social landscapes. The dominant rhetoric of identity-blind justice fails to capture such realities and thwarts the debate on the problems of a multicultural Europe. Part $V$ offers specific technical grounds for the argument that the ECJ should not review positive action policies enacted by member states. The several prohibitions of discrimination in the E.C. Treaty 
do not provide an appropriate treatment of the complex theme of positive action. The subject finds better analogues in other treaty provisions that deal more directly with the true scope of positive action-- namely, the fight against social exclusion--and that open up alternative avenues for an E.U.-wide dialogue on the rehabilitation of marginalized collective identities. [FN11]

This Article contributes to the broader discussion on the ongoing evolution of European constitutionalism. Scholars have emphasized the chasm between the "classic" method of supranational lawmaking and new, emerging forms of European governance. [FN12] The Classic Community Method reproduces, at a supranational level, the member states' modernist tradition, anxious about legitimacy, constitutionalism, and fundamental rights. [FN13] The new modes of European governance rely instead on grass-roots deliberation and enhanced political dialogue. My contribution to that discussion lies in dispelling a few myths surrounding the modernist tradition. If examined closely, mainstream policies at both national and European levels already embrace techniques for accommodating identity-based claims that a conventional rights discourse is incapable of capturing. [FN14] Addressing discrimination and exclusion by policies that combine justiciable individual rights with softer but effective forms of social inclusion is not a revolutionary move brought about by the new mechanisms of European governance, but rather a step in line with common practice and tradition, placed along a continuum of plausible institutional choices.

\section{GROUPS IN THE JURISPRUDENCE OF THE EUROPEAN COURT OF JUSTICE: GENDER AS A START}

Due to the limited competencies of the European Community, gender has been the only context in which the ECJ has reviewed state measures of positive action. Gender is, therefore, the necessary starting point of this discussion. This Part discusses a number of ECJ decisions on positive action in favor of women. The discussion highlights the elements of the Court's equality paradigm: positive action is a derogation from individual rights, to be justified in light of legitimate state goals. The Court itself is in charge of determining which state goals are legitimate, and to what extent states' positive action measures are proportionate to such goals. The analysis then identifies some of the ECJ holdings in which state initiatives in favor of women are thwarted by the weight of the Court's paradigm, highlights the risk of similar holdings in matters of affirmative action for racial, ethnic, or religious groups, and questions the legitimacy of such holdings in terms of institutional competence. In contrast to some legal scholarship on this subject, this Article does not attempt to provide a better doctrinal model for the judicial review of states' measures of positive action, [FN15] nor does it attempt to resolve the tension between group entitlements and individual rights within a coherent theoretical model. [FN16] Rather, the aim here is to show that the variables at stake in local positive action schemes are too complex, and too far-reaching, to fit comfortably within the scope of the ECJ's jurisdiction.

\section{A. The ECJ on Positive Action: First Steps}

Gender equality among workers, both formal and substantive, was on the European agenda at the very dawn of the project of integration. In the original version of the Treaty of Rome, Article 119 stated that "men and women should receive equal pay for equal work." [FN17] This principle was clearly meant to equalize the cost of labor for employers throughout the Community, to avoid price distortions due to systemic differences in production costs. [FN18] But thanks to the political success of feminist causes in the 1960s, subsequently reflected in profound transformations of family law in continental Europe, gender equality outgrew its strictly economic beginnings and became an essential part of the Community's early social policies. [FN19] In the mid1970 s, both the ECJ and the legislators of the Community began to develop the principle of gender equality in the workplace. [FN20] The Court gradually expanded the 
scope of Article 119 to include both direct and indirect discrimination against employees on the basis of gender. The refusal to appoint a pregnant woman is an example of direct discrimination, and is an immediate breach of formal equality requirements. [FN21] Indirect discrimination occurs whenever an apparently genderneutral policy results in poorer conditions for female employees. In terms resembling the U.S. treatment of "disparate impact," the Court now requests that employers justify their indirectly discriminatory policies in light of legitimate ends, and demonstrate proportionality between such ends and the means used to pursue them. [FN22]

In addition to this basic enforcement of the principle of gender equality, in 1976 the Council issued a directive permitting member states to "remov[e] existing inequalities which affect women's opportunities" in access to employment and working conditions. [FN23] In 1984, the Council of Ministers went so far as to issue a non-binding document encouraging member states "to adopt a positive action policy designed to eliminate existing inequalities affecting women in working life." [FN24]

Political consensus on the permissibility of special entitlements for female employees was relatively easy to reach. Women, after all, are neither a numerical minority, nor a group in any sense that is nationally, ethnically, racially, or religiously characterized. However, a traditional conception of equality, based on equal individual rights, continued to inform the European discourse on gender issues. Equality requires par treatment of all individuals, or differential treatment based on objective individual differences. A general prohibition against discrimination accompanies the principle of equality, and in fact it is often treated as either a synonym or as a necessary corollary of all egalitarian imperatives. [FN25] Non-discrimination rules operate, analogously, for the protection of individuals. Though they are particularly forceful when the alleged discrimination is the result of traditional biases against given groups, they are only enforced to address individual instances of inequality. In E.U. discourse, individual rights continue to occupy the center- stage.

Within this framework, the EC] has conceptualized the possibility of special entitlements for women as a "derogation from an individual right." [FN26] Such derogations, according to continental constitutional traditions, are occasionally permissible, but only if justified by legitimate goals, and only if implemented by nondisproportionate means. [FN27] States, as a consequence, must design positive action policies within the narrow guidelines provided by the principle of proportionality, as developed by the ECJ in cases of indirect discrimination. [FN28]

The potential conflict between individual rights and affirmative action, arising out of the Court's equality paradigm, came to a head in 1995 with Kalanke v. Freie Hansestadt Bremen. [FN29] The German Federal Labor Court raised the question of legitimacy of a provision mandating that employers give priority to equally qualified women in sectors where they are underrepresented. [FN30] The German court deemed the provision compatible with the German Basic Law and other statutes, [FN31] but referred to the ECJ the question of its legitimacy by E.C. standards. The ECJ, in a much criticized holding, clung to the ideal of individual rights as conceptually opposite to group entitlements for a given gender, and deemed the provision incompatible with the E.C. Treaty. [FN32] The Court explained that the plan in question was designed to guarantee the automatic result of actual employment, according "absolute and unconditional priority" to women applicants. [FN33] This exceeded the scope of the 1976 directive, only allowing for equality of "opportunities," and infringed upon Mr. Kalanke's "individual right" to non- discriminatory treatment. [FN34] The principle of proportionality and its nuances informed the opinion of the Advocate General (AG), 
[FN35] but not the Court's holding, which was based on a straightforward rejection of automatic group preferences. [FN36]

Only two years later, under heavy pressure on many fronts, the Court took a more favorable look at positive action for women, though stopping a few steps short of full endorsement. In Marschall v. Land Nordrhein-Westfalen, as in Kalanke, the German provision under scrutiny provided that, between two applicants of equal merit but opposite sex, employers should select a female employee. [FN37] This time, however, the provision contained a so- called "saving clause": the male candidate (Mr. Marschall in this case) could point out alternative criteria of preference, so as to rebut the presumption in favor of his female competitor. For instance, he could give evidence of his seniority, or of his especially acute family responsibilities. [FN38] More generally, he would be entitled to thorough consideration of his professional and personal profile. "Secondary criteria of selection" (short of chauvinistic bias) would possibly lead the employer to give him the job instead. [FN39] This saving clause, no matter how vague, eliminated the invidious automatism of gender preferences, replacing it with a personalized assessment of candidates' qualities. [FN40] This was enough, according to the Court, to do justice to the principle of equality, as well as to the axiom of individual justice. [FN41]

Kalanke and Marschall generated a flood of commentary. Some praised the Court for its somewhat Solomonic endorsement of preferential treatment for women, [FN42] while others focused their criticism on the ambiguity of the latter holding. [FN43] Some scholars particularly underlined the ECJ's endemic resistance to the concept of group justice, as well as its stern defense of individual entitlements against the specter of collective claims. [FN44] This point is particularly significant, as it raises the more general issue of shared identity in contemporary Europe. The ECJ's reply to the question of women's privileged access to the workplace might be, in fact, symptomatic of its overall attitude toward collective entitlements. The bigger question lurking behind Kalanke and Marschall is to what extent it is plausible within the European Union's legal architecture to confer any entitlements to pre-identified collectivities, even when this involves economic or political setbacks for the outsiders--a question for the twenty- first century.

\section{B. Marschall's Teeth}

Underlying the Court's reasoning in Kalanke was a sharp distinction between equality of opportunities and equality of results, the latter being prohibited by E.C. law. Marschall brought about a major change by allowing, in the presence of adequate saving clauses, preferential treatment in actual hiring-- arguably a matter of results. [FN45] In the German system, such result- oriented measures are in large part mitigated by Marschall-type saving clauses, and therefore their validity is not, at present, in dispute. Moreover, the Marschall formula still requires that male and female candidates be equally qualified for preferential criteria to apply. Meritocracy still controls; no other person in the pool of applicants has better qualifications than the person who gets the job. However, when the two safeguard mechanisms-- the saving clause and par qualifications--are not present, the $\mathrm{ECJ}$ does not approve of resultoriented schemes, also known as fixed-quota systems.

In a further case on affirmative action, Badeck v. Hessische Ministerpräsident, the EC] upheld a statute enacted by the German Land of Hesse establishing a system of "flexible result quotas." [FN46] The argument predictably raised by the applicants-that the principle of equal treatment confers rights upon individuals, and therefore "prohibits giving privileged treatment to a specific group" [FN47]--was dismissed due to the highly nuanced character of the quota system under scrutiny. Most importantly, the Hessian scheme required full evidence of equal qualifications prior to the triggering 
of gender preferences, and was riddled with exceptions. [FN48] It met, in other words, the two safeguard mechanisms required by the Marschall holding.

The rationale of Kalanke, Marschall, and Badeck sheds light on the semantics of positive action--a term chosen to distinguish European practices from U.S.- born affirmative action. The alleged distinction lies in the fact that positive action is conceptually in tune with the principle of equality, while affirmative action is not. Positive action aims at leveling the field for all players. It favors traditionally discriminated categories of individuals by allowing them to compete on an equal footing, but it does not promise them victory. It consists of a number of techniques, such as special training and educational opportunities, which do involve redistribution or diversion of resources from one group to another. Yet, according to popular European views, these techniques are only meant to allow for a fair game. Positive action is, in other words, inspired by the goal of substantive equality, which demands that unequal situations be treated differently. On those occasions in which actual hirings or promotions are based on preferential criteria, reverse discrimination might be an issue. [FN49] But individual rights are still guaranteed by merit-based assessment and by suspension or reversal of such criteria in light of specific circumstances.

While their validity by E.C. standards is beyond question, the effectiveness of positive action plans is a different matter. Where these schemes have been applied, the proportion of women in the workplace has remained static rather than having improved. One reason for this result may lie in these plans' most debatable feature-the need to demonstrate equivalent qualifications of male and female candidates before any preferential criterion is triggered. An expert of the German labor market, commenting on such data, has observed that "[i]t is fairly easy to evade decision quotas by simply denying the presence of equal qualifications." [FN50] If this is true, the type of positive action endorsed by the ECJ may be missing the real point. Such remarks may not concern the ECJ so long as its own vetting of positive action coincides with the law and policy choices prevailing in a given member state. [FN51] But the issue is one of practical importance, because some E.U. members have indeed conceived of much more aggressive plans in favor of women.

\section{Impermissible Measures: Abrahamsson and Griesmar}

When comparing highly subjective, debatable qualifications such as academic merit or aesthetics, the requirement of equal qualifications may become a stumbling block for even the most earnest positive action programs. Determining whether two applicants for the same post have equal--that is, equivalent--qualifications requires considerable discretion and value judgment. Traditional gender bias may therefore result in involuntary but systemic underestimation of female candidates' career achievements. For these reasons, a 1995 Swedish regulation, limited in scope to teaching posts in higher educational institutions, dispensed of the usual prerequisite of par qualifications: a woman possessing "sufficient qualifications for the post" could be appointed in preference to a male candidate who would otherwise have been chosen. [FN52] This rather blunt and aggressive form of positive discrimination came with a correcting device. It could only operate if "the difference between the [two] candidates' qualifications [was not] so great [as to] breach ... the requirement of objectivity in the making of appointments." [FN53] In a case recently brought before the EC], Abrahamsson $v$. Fogelqvist, these guidelines had led to the appointment of a female professor of hydrosphere sciences at the University of Göteborg. [FN54] The referring court, relying on the intervention of the Swedish government, validated the reading of the constitutional principle of objectivity as applied at the University of Göteborg. In the implementation of the relevant affirmative scheme, high academic standards had been preserved; administrators struck the right balance between the objective assessment of candidates' overall qualities and the need to promote gender equality in 
academia. [FN55] The EC], however, did not find this analysis persuasive. The Swedish scheme could not pass muster for a number of reasons: (a) it contained no saving clause for the male candidate and therefore operated in an impermissibly automatic fashion; (b) it did not use, in the assessment of candidates, sufficiently clear and unambiguous criteria; and (c) to the extent that it pursued the legitimate goal of compensating for women's professional disadvantages, it did so disproportionately. [FN56] If proportionality is not respected, gender preferences cannot meet the equality standards of the Union, and remain impermissible derogations from individual rights. [FN57]

The Commission welcomed the Abrahamsson decision. Interestingly, on its official Web site, the Commission advertised the case as one that "upheld Swedish measures to combat female under-representation in employment." [FN58] This is only partly true. The Court did confirm the permissibility of positive discrimination in favor of women, and explained that gender may operate as a tie-breaker once a tie is established, thereby rejecting with unprecedented clarity the logic of Kalanke. [FN59] However, Abrahamsson significantly curtailed the scope of the Swedish regulation in question. The administrators of the University interpreted it to mean that, because the principle of objective assessment was not violated--the female candidate was certainly worthy of that academic post--the requirement of par qualifications could be mildly relaxed. Quite to the contrary, after Abrahamsson, the formalistic threshold of equal qualifications must be unquestionably met. The female candidate must be just as good as her male competitor. It is only at that point that, rather than tossing a coin, University deans can use gender as a basis for their final decision.

This case reveals a serious clash of attitudes between the ECJ and a member state on affirmative action. In the view of the Swedish establishment, the Marschall prerequisite of par qualifications is clearly inadequate to address representational deficiencies in the academic community. Yet, it continues to control the supranational legitimacy of positive action policies.

Supranational scrutiny takes the shape of a proportionality test. Through the principle of proportionality, state measures on group affirmation can be reconciled with equality. The test of proportionality consists of three parts: (a) whether a given legislative or administrative measure aims at a legitimate goal; (b) whether the challenged measure is in fact necessary to pursue the identified goal; and (c) whether the means envisaged are not disproportionate to the goal pursued. Proportionality has, for many years, guided the $\mathrm{ECJ}$ in determining whether Community legislation, or state action in an area of Community competency, oversteps the boundaries of means-to-ends proportion. [FN60] Unquestionably, each step of this scrutiny engages the Court in a delicate balance of institutional competencies, and in the extremely complex art of ranking, by importance, multiple policy objectives pursued by national lawmakers.

The bulk of proportionality review is to be found in the Court's control over state measures impinging upon the free movement of goods, services, or persons for the alleged purpose of protecting public health or public order. In these contexts, the ECJ's institutional or actual competence to handle proportionality review is often taken for granted. One may question, however, the usefulness or propriety of proportionality review in positive action cases. In an article on proportionality in E.C. law, Gráinne De Búrca wrote:

In certain specific political contexts ... courts tend to be considerably more deferential in their review. They are more reluctant to adjudicate if the interest affected is seen as a collective or general public interest rather than an individual right, and if the interest of the State is a mixed or complex one, e.g. in an area involving national economic and 
social policy choices .... Or even if [the challenged measure] does affect a recognized right, [it may be that] it also concerns many other interests, both individual and general, over which the policy maker has presumably deliberated at length in coming to a decision .... The ways in which a court may defer in such circumstances range from deeming the measure non- justiciable, to refus[ing] to look closely at the justification for [its] restrictive effects .... [FN61]

As a matter of fact, where doubts have arisen as to its full understanding of the means-to-ends inquiry in a given sociopolitical context, the ECJ has engaged in selfrestraint, leaving national courts in charge of the final findings. [FN62] But selfrestraint is certainly not the keynote of positive-action scrutiny. With Abrahamsson, the ECJ has taken upon itself the role of arbiter on such issues as the means used to achieve diverse representation in academic institutions. It has also claimed competency to second-guess that state's educational values: traditional scholarly ranking, according to the Court, must still prevail over more rounded concepts of objectivity, even when the local governance has come, over time, to a different conclusion. [FN63]

D. Positive Action and the European Union's Constitutional Asymmetry The top-down, supranational definition of such complex social matters as positive action in the European Union is particularly troublesome in light of the Union's "constitutional asymmetry." [FN64] In the enforcement of the E.C. Treaty's fundamental freedoms (providing for virtually untrammeled transborder circulation of goods, workers, services, and capital), the ECJ finds itself endowed with tremendous deregulatory powers. By contrast, when it comes to the task of devising new regulatory projects for Europe, E.C. institutions find innumerable obstacles in the substantive and procedural provisions of the treaty. In matters of pensions and retirement benefits, for example, E.C. courts and legislators can force member states to abolish all forms of discrimination based on nationality. States may also have to equalize pension benefits for men and women. [FN65] But the possibility of redesigning, through E.C. secondary legislation, the substance of retirement benefits is quite meager. [FN66] Analogously, the European Union cannot impose its own vision of incentive measures to promote gender equality in the workplace, but must limit itself to encouraging states to come up with effective plans. Against this background, the recent ECJ holding in Griesmar v. Ministère de l'Economie, des Finances et de I'Industrie illustrates how the supranational scrutiny of states' positive action programs may create an unwarranted legislative deficit in crucial social matters. [FN67]

Griesmar came to the attention of the ECJ upon reference from the Conseil d'État. [FN68] Article L12b of the French Civil and Military Retirement Pensions Code mandated special pension credits for female civil servants. [FN69] For the purposes of computing pension allowances upon retirement, women were entitled to a virtual lengthening of their years of service: one year per child, depending on motherhood only, and not on actual maternity leaves interrupting their employment. [FN70] In $1999 \mathrm{Mr}$. Griesmar, a French magistrate and father of three children, claimed to be entitled to the same benefit. The Conseil referred the case to the ECJ for a preliminary ruling on the compatibility of the provision with Community law on gender equality.

The Court noted that the provision in question, according to its preparatory documents, was originally meant to induce female employees to suspend work and take care of their babies for a while, without fear of losing any of their pension rights upon retirement. [FN71] By this logic, the provision was unduly overinclusive, as it also applied to women who had not taken any time off due to maternity. But it was also underinclusive, and discriminatory, insofar as it did not apply to those fathers who happened to shoulder the child-rearing burden. 
The arguments of the French government in favor of Article L12b's legitimacy were very different. In the government's view, the purpose of that provision was: to address a social reality, namely the disadvantages which [female civil servants] incur in the course of their professional career by virtue of the predominant role assigned to them in bringing up children. The purpose of [the pension credit was] thus to offset the disadvantages which female civil servants who have had children encounter in their professional life, even though they have not ceased working in order to bring up their children. [FN72]

This may be true, the Court reasoned, but not enough to withstand Griesmar's rebuttal. As in Marschall, the Court was unwilling to go along with stereotypes, even when stereotypes coincided with well-established features of task-allocation in the family. Applying its Marschall formula, the court stated that if a male civil servant proves that he did, in fact, bring up his children, he must be entitled to the same benefit. [FN73] The presumption that mothers--even full-time working mothers--do most of the child-rearing work must be lifted if Mr. Griesmar and other fathers can prove it unwarranted in light of personal experience. Article L12b of the Pensions Code was therefore at odds with the Union's gender equality law insofar as it did not contemplate this possibility. [FN74]

Once more, there are reasons to doubt the sensibility of the Court's holding. In terms of strict logic, it may be a straightforward application of the Court's understanding of equality. Viewed in terms of European social engineering, however, Griesmar holds much less persuasive force. There are many ways in which the state, as employer, may encourage women to join the workforce. In many European states, it is thanks to employment in the public sector, and to special accommodations for the protection of the family, that women are adequately represented in the workplace. [FN75] The Pensions Code's preference may well have made sense in the French design of public employment, but the Griesmar holding interferes with that design. It is de- regulatory, and very effectively so, thanks to the immediate enforceability of ECJ holdings. But it does not, and cannot, point to reconstructive suggestions, because social engineering at large is not within the competency of the Union. Holdings like Griesmar do not relieve member states of the task of designing optimal formulae for a diverse workplace, and yet burden them with deregulatory constraints. [FN76]

\section{E. Positive Action Beyond Gender: The New Equality Directives}

The Treaty of Amsterdam, signed in 1997 and effective as of May 1, 1999, modified the original Article 119 on gender equality by adding to it an explicit, though vague, endorsement of positive action. [FN77] The new Article 141 is now the only provision in the Treaty making explicit room for positive action. Gender, however, is only one of the many grounds for discrimination outlawed by the E.C. Treaty.

Acts of discrimination among Community workers on grounds of nationality were prohibited at the very start of the integration project as clearly in conflict with the idea of a seamless labor market. [FN78] Discrimination on grounds of nationality was also subject to a general prohibition, ranking among the "Principles" of the Treaty of Rome. [FN79] In 1997, the Amsterdam reform empowered E.C. lawmakers to "combat discrimination based on ... racial or ethnic origin, religion or belief, disability, age or sexual orientation." [FN80] Just like the prohibition against gender discrimination, these provisions are underpinned by the logic of a seamless market, as they clearly promote the mobility of labor and the equalization of labor costs throughout the Union.

At the same time, non-discrimination articles also expand the legal basis for E.C. action in social matters. Article 13 was soon invoked as the legal basis for two new pieces of 
anti-discrimination legislation. Council Directive 2000/43 implements the principle of equal treatment between persons irrespective of racial or ethnic origin. [FN81] Council Directive 2000/78, in furtherance of the same project, addresses more broadly "discrimination based on religion or belief, disability, age or sexual orientation," and aims at establishing a general framework for equal treatment in matters of employment and occupation. [FN82] The preamble to the Framework Employment Directive makes it clear that gender equality in the workplace and equal treatment at large are really pieces of the same puzzle to be dealt with as an indivisible set of policy questions. [FN83]

Both directives, which member states are currently in the process of implementing, were issued in the year 2000, the same year in which the ECJ decided Abrahamsson. Both directives seem remarkably tolerant of member states' choices with regard to group protection, and contain the following provision: "Positive action--With a view to ensuring full equality in practice, the principle of equal treatment shall not prevent any Member State from maintaining or adopting specific measures to prevent or compensate for disadvantages linked to [the above-listed characteristics]." [FN84] This text is entirely in line with E.C. Treaty Article 141(4), which permits states to pursue the strategy of positive discrimination well beyond the limits imposed by a formal conception of gender equality. [FN85] And just like Article 141(4), the directives leave plenty of room for the Court to scrutinize state measures. [FN86] It is not clear how the new legislation will coordinate with existing laws in coterminous fields--most importantly, the 1976 directive on gender discrimination--and with the case law of the EC] in equality matters. It is likely, however, that the rather bulky body of judicial holdings regarding discrimination based on gender will provide firm guidelines for the interpretation of the new directives. This option would promote clarity and uniformity. [FN87] It would also extend to race, ethnicity, and religion the impressive level of awareness, legislation, and enforcement of non- discrimination rules achieved in gender matters. For these reasons, the extension of gender discrimination jurisprudence into other areas is a desirable option. [FN88] But when it comes to positive action, the legacy of gender cases decided by the ECJ thus far may pose serious risks. [FN89] The new directives attempt to strike a compromise between the need to ensure uniformity in the enforcement of equality, and member states' aspirations to engineer their own models of diverse society. As Abrahamsson and Griesmar demonstrate, it is far from clear that this delicate architecture will survive challenges before the ECJ. The Court may soon have to face national instances of positive and affirmative action in fields that are much more controversial than gender, while relying on the rather rudimentary analytical framework developed around women's issues. [FN90]

\section{POSITIVE ACTION, EQUALITY, AND INDIVIDUAL RIGHTS IN E.U. LAW} Within the conceptual framework of the ECJ, positive action appears to be inherently at odds with equality, because it involves privileging a subset of citizens while failing to take account of actual differences and similarities between individuals. [FN91] Even in its mildest version, it is, indeed, a form of differential treatment, and implicates issues of collective justice. For positive action to exist, there needs to be a formula capable of restoring the internal consistency of the rule of law. [FN92] The formula must be justiciable, and designed to screen away those forms of positive action that would compromise the coherence of the equality architecture. As illustrated in Part II, the ECJ has determined that the test of proportionality can accomplish this task, ensuring that states' pursuit of equality by means of positive discrimination does not violate the canons of equality. The core of individual equality is still preserved by means of formal devices: saving clauses, strict meritocracy, illegality of result-based or "hard" affirmative actions, inadmissibility of firm quotas of representation, and so on, are all mechanisms meant to ensure that the group in need of protection has not taken over, 
and that all other individuals outside that group can still rely on the judicial protection of their ultimate right to equal treatment.

In the specific context of E.U. law, this understanding of positive action leads to a particularly thorny conundrum. Both according to the new equality directives and under E.C. Treaty Article 141(4), the principle of non- discrimination acts as a floor, rather than a ceiling. The Union is in charge of prohibiting discrimination in its classic, negative form: no one can be treated differently on the basis of ethnicity, religion, etc. At the same time, states can aim at higher degrees of substantive equality by enacting measures of preferential treatment for groups traditionally discriminated against, depending on local context and politics. This construct has the comforting flavor of subsidiarity [FN93] and the support of considerable experience in the field of gender equality. The problem with this construct is that, as usual, the structure of the floor imposes limits upon the height and shape of the ceiling. The two are so conceptually intertwined that the states' freedom to experiment with affirmative group policies, given them by E.C. legislators, is intrinsically curtailed by the ECJ's equality review.

The need for an internally coherent picture, bringing into harmony the ECJ's enforcement of equality and national positive action policies, is overstated for theoretical and empirical reasons. In E.U. law, one finds both a strong emphasis on individual rights, and a political commitment to redress collective inequalities.

A. The Uncertain Boundaries of Equality in the European Union The doctrinal architecture that leads the Court to such holdings as Abrahamsson rests, ultimately, on the time-honored pillar of formal equality. This pillar, however, is not as structurally sound as it seems. There is no coherent vision of equality in the project of European integration. [FN94] The prohibition against discrimination features in a number of scattered provisions, and it is only thanks to the painstaking work of the $\mathrm{ECJ}$ that it has developed into "the general principle of equal treatment" as we know it today. [FN95] The principle arguably is not general, and if measured by standards of coherence, it may not even be an E.U. principle at all. [FN96]

There are many policy areas in which the principle of equality is not meant to control. The new equality directives illustrate this point. The path to their adoption was paved with the best of intentions. In 1997, the "European Year Against Racism," the Union embarked on a series of projects aimed at combating racial discrimination in all of its forms. [FN97] The directives, however, are encumbered by the hybrid nature of supranationalism, which splits competencies between Brussels and state authorities along the often illogical lines of historical development. [FN98] For E.C. legislators, the impossibility of thoroughly regulating the status of third-country nationals residing in the Union seriously compromises the coherence of the directives. [FN99] The result is, once more, the coexistence of different standards of equal treatment, depending upon possession of an E.U. passport rather than upon universal values. [FN100] Thus far the E.U. establishment has taken for granted that equal treatment would only pertain to E.U. citizens. To be sure, by signing a number of association agreements with third countries, E.U. members have allowed the nationals of some non-member states to join the club of the non-discriminable. [FN101] This move has shifted outwards the geographical boundaries of certain Community guarantees. The fact remains, however, that many foreign nationals permanently residing in Europe do not yet enjoy the protection of the equality principle.

At the same time, the Court's intervention in equality matters can be quite inclusive. In theory, in all those fields that exceed the reach of Community competence, states would not have to comply with European non-discrimination principles. In practice, this line is not so easy to draw. For instance, some social benefits are covered by the 
principle of equality, and some are not, depending on policy considerations. [FN102] More generally, there is still no firm definition of the set of "situations governed by Community law." [FN103] And even when clearly not within that set, a subject matter may be reached by the long arm of equality jurisprudence. For example, social security falls outside the sphere of Community competence, but the Court has held that states' social security laws cannot discriminate against other member states' nationals. [FN104]

These uncertainties cast preliminary shadows upon the equality-based syllogism motivating the ECJ's holdings on positive action. The picture becomes even less clear if one focuses on the axiom that equality must be understood in terms of individual justice, and cannot accommodate measures based upon collective identity. A series of legislative measures, administrative practices, and judicial opinions emphasizing the relevance of collective identity policies in the European Union's vision of justice regularly contradicts the rhetoric of individuals rights--a rhetoric powerfully echoed in the ECJ's holdings on positive action.

B. The E.U. Theorem of Individual Rights: Historical and Economic Foundations The legal integration of Europe is traditionally founded upon an individual conception of rights and entitlements. This feature stems from the Union's historical premises. The EEC was born out of the ashes of World War II. [FN105] The power of its design relied on the promise that, thanks to economic integration, conflicts on the scale of what was just experienced would be hence-forth impossible. The founding fathers of the Community, in whose minds the horrors of the Holocaust were still very vivid, would have been righteously contemptuous of identity-based entitlements. Group rights were also largely discredited in international law and politics due to the failure of the League of Nations' minority protection scheme. [FN106]

This ideological aversion to group rights in the late 1940s also characterized the parallel development of the Council of Europe. [FN107] The 1950 European Convention for the Protection of Human Rights [FN108] and Fundamental Freedoms had little or nothing to say on the issue of group affiliation. [FN109] The Convention's nondiscrimination clause [FN110] was conceived as merely accessory to whatever substantive rights might stem from other provisions. A recently added Protocol 12 promotes that clause to the status of a fundamental right to non-discrimination. [FN111] The Protocol's preamble recites that states will not be prevented from taking measures to promote "effective equality," [FN112] but its main body remains silent on positive action. A half-century later, it is still the case that "the Convention and its control system ... are based on the collective guarantee of individual rights which are formulated in terms sufficiently specific to be justiciable." [FN113]

During the foundational period of the Community, a number of landmark ECJ decisions reinforced the original emphasis on individual justice. The centrality of individual subjects proved to be a clever state-breaking device, meant to enhance the supranational strength of the "new legal order." [FN114] By dispensing rights immediately enforceable by individuals, the Community could bypass the filter of states' authority, rendering states' mediation unnecessary. In this light, the doctrine of direct effect represents the quintessential triumph of individuals over their community of formal affiliation. [FN115]

Another ideological force driving the economic project of integration was a faith in the freedom of market actors, couched in ordo-liberal theory. [FN116] According to that strain of thought, integration was to be achieved by protecting individual market players from overbearing government intervention. State interference with private enterprise would be appropriate only to enforce the rule of (private) law in horizontal 
transactions, subject to a sort of "economic due process" clause. Competition law would help guarantee sufficient leeway for individual action. The connection between individual fundamental freedoms and the "economic constitution" of the Union continues to be strong. [FN117]

This conception of equality yields, as necessary byproducts, a number of basic concepts easily reducible to pairs of opposites. First comes the goal of market integration, which presupposes the dismantling of a great deal of state regulation, and the protection of market freedom for all individuals. In this atomistic view of market actors, there is no room for groups, or for group justice. In a free market, rights are for individuals only. They are fundamental "liberty" rights, to be protected by negative means (i.e., prohibition against all encroachments from either private groups or government) rather than by positive channeling of the spontaneous forces of the market. Liberty rights are adequately protected by a formal enforcement of equality. Substantive or factual equality cannot and should not be attained by means of law, but perhaps within the separate sphere of politics. Put differently, the law will only protect equality of opportunities, not equality of results.

The dichotomies embodied in this discourse survive in the daily practice of Community law: individual versus group, form versus substance, opportunities versus results, negative versus positive integration, and law versus politics. The rhetoric of individual rights is still informed by such archetypes.

\section{Individual Rights and Equality in Contemporary Europe}

The Charter of Fundamental Rights of the European Union, solemnly proclaimed by the European Union's Heads of State in 2000 but not (yet) an official source of binding law, is firmly anchored upon an individual conception of rights. [FN118] It permits derogation from equal treatment of men and women in matters of employment, [FN119] thereby reflecting the current version of E.C. Treaty Article 141(4). A separate article promises respect for cultural, religious, and linguistic diversity, but not in a manner that might support the legitimacy of identity-based preferential treatments. [FN120] The charter does incorporate social rights, which would certainly lead to the enactment and enforcement of policies at least implicitly designed to address marginalized minorities. "The social," however, can be conceptualized as identityneutral; it does not conflict with the principle of equality insofar as it targets all people who happen to fall below a certain standard of living due to their income. And it is a fundamental tenet of our times that being destitute is (hopefully) a transient condition, rather than an immutable characteristic. It is thanks to this syllogism that the welfare goal of reaching out to those in need is deemed perfectly compatible with the logic of egalitarianism. [FN121] The rhetoric of neutrality, however, hinders the reach and scope of social reform, and puts the Union in the unpalatable role of curbing some social initiatives of state governments.

Public procurement offers a clear example of this phenomenon. The European Community has legislated in the field of public procurement with the clear objective to prevent member states from favoring local business and discriminating against firms based elsewhere in the Union. [FN122] As always, the principle of non-discrimination is achieved by the enforcement of equality. Here, equality is promoted by anchoring the selection process to purely economic criteria. This serves the purpose of forcing national protectionism out of the picture. But it also eliminates, as an unnecessary byproduct, the use of other social criteria by states that might have otherwise been taken into account in choosing the most appealing bid. Exceptionally, "[c]riteria involving social considerations may be used to determine the most economically advantageous tender where they provide an economic advantage for the contracting authority," [FN123] but social goals per se cannot inform the selection process. By this 
token, minorities cannot benefit from preferential treatment in public procurement. The impossibility of granting minorities any special status in public procurement results, allegedly, from no less than international obligations: the commitments undertaken by the member states in the Agreement on Government Procurement, [FN124] concluded under the auspices of the World Trade Organization, are "incompatible" with quotas or other privileges for special categories of bidders. [FN125] Preferences of any kind are excluded, moreover, by "the general principle of non- discrimination." [FN126]

The choice not to allow for identity-based criteria in the selection of tenders is, unquestionably, a political one. It is mandated by reasons of convenience and a balance of interests in the international sphere. It is a choice made against a background of plausible alternatives. [FN127] Instead, the Commission advertises its choice as the compelled result of fundamental legal principles in the Community, such as non-discrimination and compliance with the rule of law. This rhetoric stifles any debate on the topic.

D. The Other Theorem: Identity Matters in E.U. Law

The commonplace portrait of E.U. law's indifference to collective identity in Europe--the very portrait upon which the EC] grounds its own positive action jurisprudence-provides only part of the picture of the European equality discourse. The Union is based upon the principle of equal individual rights, but it is, at the same time, quite involved in the recognition, protection, and proactive enhancement of groups.

Ambivalence on such matters is endemic to the E.U. system. As observed, individuals are central to the project of integration; they are primary holders of legal entitlements. At the same time, the decline of the very concept of the nation-state is essential to the success of the integration project, and as nation-states fade away, sub- or transnational communities defined by common ethnicity, language, or religion come to the fore seeking enhanced status. [FN128] The Union provides transnational communities with communication channels that transcend state boundaries, and with institutions that enjoy supremacy over state actors. The fight against discrimination is only one form of assistance toward marginalized groups. Collective identity is not only conceptually relevant, but also an essential factor in certain redistributive policies at the E.U. level.

Culture is of particular significance in providing groups with special entitlements without upsetting in any visible way the assumption of identity- blindness in the distribution of resources. Speaking the politically palatable language of "cultures," E.U. policymakers enhance, by means of tangible aids, the meaning and visibility of ethnic, religious, or linguistic groups.

The Directorate General for Education and Culture is becoming increasingly involved in the question of immigrant identities. In cooperation with a number of state universities, for instance, in 1998 the Directorate launched Euromed Heritage, a "regional programme in support of the development of Euro- Mediterranean cultural heritage." [FN129] The program provides generous funding for such events as the "Unimed Symposium," a conference on the "intangible cultures" of Southern Europe, North Africa, and the Middle East. The official Web site of the Directorate, in unmistakably postmodern jargon, defines "intangible culture" as "a set of values linked to the collective memory and to the imaginary that contribute to the identity of ... each social group." [FN130] In all such programs, the wording is airy. Rights--cultural or social--are not implicated. There are no justiciable claims. But identity-based redistribution of Euro funds occurs nevertheless. 
In fact, the cultural strand of identity discourse is often more prominent in E.U. lawmakers' agendas than in the agendas of member states. Sub- or transnational groups defined by common language or ethnicity, which fail to identify with traditional nation-state boundaries, and which struggle for survival, receive significant supranational attention. In turn, such groups can perform a state-breaking function and advance the cause of integration. The subject is coterminous with human rights protection, but differs from human rights discourse insofar as it implies necessarily the sheltering of collective identity from atomistic dilution and assimilation. The protection of cultural diversity requires, in other words, positive action by government, surely defying the principle of formal equality. "Negative" anti-discrimination policies will not suffice. [FN131]

Central to the livelihood of separate cultures is the survival of minority languages. The ECJ's case law on the protection of minority languages contains significant overtures toward group recognition. [FN132] To be sure, the Union's commitment to minority languages is burdened by institutional limits, due to the complex legacy of the economic integration project. [FN133] The European Union is still struggling to identify a clear balance between the protection of linguistic or ethnic traditions and the seamless integration of the market. The goal of protecting the identity of minorities may be in conflict with economic integration and its promises of free trade and travel. In these cases, the Court feels compelled to dilute collective identities in order to iron out the seams of state borders. [FN134] The Court's qualms, however, do not depend on concerns for identity-blindness. There is no fear, in this context, of trumping the rights of the majority by aiding identified minorities. It is understood that the survival of minority languages is a legitimate goal justifying the redistribution of economic resources in favor of supporting linguistic minorities. [FN135]

When market partitions are not immediately at stake, the European Union is indeed quite generous in its validation of groups' cultural or linguistic demands. The Union has helped finance various programs meant to support the existence of minority languages and cultures. [FN136] Basis for such action has been found either in E.C. Treaty Article 151 , which asks the Community to contribute to the "flowering of the cultures of the member States," [FN137] or in the more traditional provisions favoring the free movement of workers. For instance, EEC Treaty Article 49 (now E.C. Treaty Article 40) was the basis for Council Directive $77 / 486$, ensuring education in the official language (or one of the official languages) of a member state for children of migrant workers. [FN138] In this context, cultural goals merge with the workers' right to adequate education for their children. [FN139]

Together with the Council of Europe, the Union inaugurated the new millennium with a "European Year of Languages." [FN140] During 2001 the Commission funded a number of innovative learning projects, covering not only the official languages of the member states but, more significantly, regional and minority languages as well. [FN141]

Union policies have targeted not only the cultural vitality of minorities, but also their material welfare. "The social" is an important piece in the constitutional architecture of the Union, and it finds many incarnations in secondary legislation and policies. Welfare, understood as redistribution of resources in favor of those in need, has seemingly nothing to do with identity because it targets poverty and exclusion wherever they happen to be. Yet identity-sensitive criteria are often used to improve the effectiveness of re- distributive policies. The European Monitoring Centre on Racism and Xenophobia (EUMC)--an E.U. agency established in 1997--is tasked with the reduction of existing discrimination in Europe. It is also actively involved in the socioeconomic promotion of minority groups. Through the EUMC, the European Union spends money in connection with policies that identify specific disadvantaged groups on the basis of ethnicity or 
nationality. This practice is not immediately visible. The EUMC offers indirect but substantial support to a number of projects for the rehabilitation of minorities, which are in turn run by independent and state-funded foundations. Among these projects, coordinated through the EUMC and financed in ways that erase the public-private divide, one finds several forms of positive action in favor of identity-defined groups in the fields of education, housing, and employment. [FN142]

E.U. regional intervention by means of structural funds may be regarded as an even subtler instance of allocation of E.U. resources on the basis of identity. [FN143] Target areas are defined in purely geographical terms, with no reference to the ethnicity or nationality of their inhabitants. But it is often the case that specific communities, characterized by common values and origins, are in fact singled out as the recipients of E.U. aid. In Germany, for instance, E.U. structural funds given to the region of NorthRhine Westphalia-- home to many Turkish immigrants--are used to bolster local startup businesses, effectively targeting an ethnic group with job growth and educational programs. [FN144] In such schemes, the distinction between opportunities and results is particularly difficult to maintain. Along the continuum of identity- based redistribution, this form of intervention may be less conspicuous than affirmative action, yet it is inspired by the same logic.

E. Redistribution Unchallenged: Affirmative Action Between Law and Politics Interestingly, the redistributive policies just mentioned are not usually expressed through rights discourse and remain unchallenged. This may be explained, in part, by the relative opacity of these mechanisms, [FN145] and by the myth that the mechanisms themselves are based on allegedly neutral criteria of selection (poverty, marginalization, etc.). Furthermore, the Commission and other E.U. actors enjoy ample decisional leeway in the implementation of such programs. European Union policies must find support in specific acts of secondary legislation, [FN146] but the actual administration of resources and selection of beneficiaries are left to the discretion of the Union's executive powers. Yet discretion alone does not explain the lack of judicial challenges. Discretionary acts of the Union's executive, like all Community acts, are subject to judicial review, and therefore to the constraints of such general principles as equality and proportionality. [FN147] Why then are the mechanisms of redistribution exemplified in the preceding section not likely to undergo judicial scrutiny before the ECJ?

The broader context provides a likely explanation. The Union, just like the member states, has a composite political mandate, embodying both traditional liberal rights imperatives and social aspirations to solidarity. [FN148] In some cases the obligation of solidarity is more obvious than in others, and the goals pursued by redistributive measures are subject to little dispute. The creation of jobs for immigrants is, indeed, a form of reallocation of resources, and one that may even grant automatic privileges to people of particular ethnicity or religion. However, if there is sufficient political consensus on the need to redress the traditional disadvantage of those immigrants, privileges are conceptualized not as positive or affirmative action, but rather as a practical implementation of substantive equality. On the other hand, when the identified need does not meet general consensus, catering to it may look like positive discrimination, arguably illegitimate or disproportionate. European Union policies, even though targeting identity-based groups, escape equality challenges insofar as they are supported by sufficient political consensus, and if perceived by the Union's constituency as necessary to the goal of substantive equality.

\section{F. Redistribution and Positive Action in the Member States} When it comes to redistributive policies enacted by member states, the traditional attitude of the Union is one of non-interference. Member states are mostly in control of 
direct taxation, for instance. [FN149] Fiscal policies--the most conspicuous form of redistribution in western societies--are legitimate insofar as the diversion of resources they imply is warranted by political consensus as expressed by each state's constituency. The same is true for welfare and most economic policies, subject to the aggregate, quantitative constraints imposed by the Monetary Union, but free of supranational control in terms of quality and overall design. Vivien Schmidt has observed, poignantly, that

[t]here is ... certainly no European welfare state in the offing .... This is not only because of the near-impossibility of such a task, given the diversity and complexity of national social security systems, but also because of ... an 'asymmetrical' EMU in which the monetary was highly developed and the economic only minimally. [States] did not want to consider national fiscal and social policies or the issues of wealth distribution at the European level, convinced that the issues were too politically sensitive and better left to piecemeal, national-level changes in response to the pressures of market forces. [FN150]

It is within this context that the Union should conceive of states' positive action programs. In any form--with or without saving clauses, targets, quotas, or merit-based controls--affirmative measures in favor of marginalized minorities can be thought of as ways to redistribute wealth within a given constituency from one group of subjects to another. [FN151] Redistribution of resources may take many forms. Positive action is, indeed, a peculiar form of redistribution, as it is based on collective identity rather than upon income or other (supposedly) neutral criteria. But in this regard it is not unique. On the basis of its socioeconomic function, positive action belongs on a continuum of multiple forms of identity-based redistribution of resources. Along this continuum, positive action shares the same logic of many other state policies that the ECJ could not, and does not, review in traditional equality terms. Locating positive action along a continuum of redistributive schemes shows how individual equality is an inappropriate analytical framework for the purpose of determining the legitimacy of such policies.

\section{BLIND JUSTICE AND IDENTITY-BASED REDISTRIBUTION IN THE LEGAL LANDSCAPE OF \\ THE MEMBER STATES}

This Part identifies a gap between the reality of states' policies and the ECJ's equality paradigm in positive action cases. A number of French regulations or programs that target specific minorities will illustrate this point. These examples are also meant to support a claim that has growing resonance among political scientists: the continental rhetoric that rejects multiculturalism coexists, in practice, with policies favoring plural identities in the public space. [FN152] The French experience can be generalized to identify those features of European discourse most often employed to justify otherwise impermissible practices of identity-based allocation of resources. These practices belong on a continuum of redistributive state policies, which may exceed the scope of supranational competence and therefore should not be subject to equality review before the ECJ.

A. Limits of the Equality Paradigm: Lessons from the Member States At a crucial point in the history of European integration, the ECJ began to write its own chapter on fundamental rights. This judicial move was strikingly radical, as it lacked textual basis in the Treaty of Rome and marked a clear departure from the purely economic foundations for integration of the 1950s. [FN153] At the same time, however, the move fell well within the prediction of neo-functionalist analyses: any integration effort, no matter how narrowly conceived at its start, would bring about the unavoidable spillover effect of jurisdictional expansion. [FN154] Most cautious in its early steps, the ECJ ventured into the uncharted territory of Community fundamental 
rights by pledging deference to the member states' established authorities: "In safeguarding [fundamental] rights, the Court is bound to draw inspiration from constitutional traditions common to the Member States." [FN155]

For the sake of the "uniformity and efficacy" of European law, [FN156] the Court also made clear that national constitutions would not control the Community's fundamental rights jurisprudence, which would be ensured within the Community's very own "structure and objectives." [FN157] To this day there is no clear solution to the built-in ambiguity of European fundamental rights. [FN158] The EC] has long proceeded in the hope that its own views on such issues and those of the member states' legal actors would never clash. Recent developments--most noticeably the Charter of Fundamental Rights [FN159]-are not expected to assuage, technically [FN160] or even symbolically, national worries of encroachment, as expressed by the German Constitutional Court in its Maastricht decision. [FN161]

The sphere of equality is no exception. Equality, in the ECJ's view, is not only a general principle of Community law, but also a "fundamental human right" not to be discriminated against. [FN162] In enforcing the fundamental right to equal treatment, the ECJ has traditionally kept in tune with member states' constitutional guidelines. The new E.C. Treaty Article 13, providing the Court with an independent legal basis for its adjudication of equality, does not really change the status quo. If nondiscrimination were to take a form of its own in E.C. law, substantially diverging from member states' understanding of equality, the reasoning behind the Maastricht decision might lead to constitutional disobedience. [FN163] In dealing with issues of equal protection and relegating positive action to the status of "derogation," the EC] cannot be exclusively self-referential.

In 1995, when the Court decided Kalanke, its reception of national views took the shape of a short, matter-of-fact remark by AG Tesauro: "[T] he principle of equality as between individuals ... is safeguarded in most of the member states [sic] legal systems." [FN164] To some extent, this perception is still defensible today; but things are changing. Because marginalization may be due to social biases against particular ethnicities or religions, Europe's profound commitment to social causes may require the invocation of "suspect categories" as criteria for the identification of disadvantaged groups in order to effect change. [FN165] Targeting groups of pre-defined identity for the distribution of social benefits such as subsidized housing, education, and financing is a strategy employed, as illustrated below, even in most identity-blind systems. These changes make it more difficult for the ECJ to cling to the coherent vision of individual equality outlined in the context of gender. The following sections illustrate that the law of the member states is much more receptive to groups, identity, and ethnicity than what the dominant rhetoric of individual rights may concede.

\section{B. The "Dilemma of Diversity" in the Member States}

[W] hen does treating people differently emphasize their differences and stigmatize or hinder them on that basis? And when does treating people the same become insensitive to their differences and likely to stigmatize them on that basis?

... The problems of inequality can be exacerbated both by treating members of minority groups the same as members of the majority and by treating the two groups differently.

... Governmental neutrality may be the best way to assure equality, yet governmental neutrality may also freeze in place the past consequences of differences. [FN166] 
The "dilemma of difference," identified by Martha Minow in the U.S. context, characterizes the legal landscape of the E.U. member states. Some governments are traditionally at ease with the recognition of ethnicity, religion, or national origin in official statistics, [FN167] and even with the practice of explicit affirmative action in favor of groups identified by such characteristics. In Northern Ireland, the 1989 Fair Employment Act allows the Fair Employment Commission to instruct employers to take "hard" affirmative action measures to remedy the underrepresentation of Protestant and Roman Catholic communities in the workplace. [FN168] In the Netherlands, some forms of affirmative action in the civil service allow preferential hiring of candidates having adequate, and not necessarily equal qualifications. [FN169] Sweden, too, has occasionally resorted to veritable quotas for ethnic minority members. [FN170] As observed in Part II, these plans would exceed the narrow standards imposed by the EC] upon states' positive action measures. [FN171]

In other states, for reasons ranging from history to politics and philosophy, the rhetoric of individual rights is far more powerful and yields a different official discourse. France, for instance, purports an identity-neutral vision of equality, and does not employ overt measures of positive or affirmative action in favor of ethnic, racial, or religious groups. [FN172] French policies in favor of the disadvantaged are cast in origin- or faith-blind terms, and are unlikely to be affected by the ECJ's proportionality scrutiny. Identityblind equality is a common paradigm in other E.U. states as well. [FN173] Most noticeably, Germany displays a constitutional aversion to affirmative action and to group recognition in general, due to the still horrifying memories of German crimes in World War II. [FN174] In Germany, however, ethnicity and religion are legally visible, and clearly inform a number of traits specific to that legal system. [FN175] In France, by contrast, identity blindness is a pervasive feature, epitomized by the lack of official statistics on the origin of French citizens and by a firmly secular vision of governance. Its model of a color-blind, absolutely neutral law is particularly strong. [FN176] At the same time, France is characterized by a remarkably diverse population, and by particularly visible political tensions around the issue of multi-ethnicity. The dilemma of diversity is therefore especially obvious in the French legal landscape.

\section{The Case of France: Identity Blindness ...}

Article 2 of the 1958 French Constitution assures equality without distinction based on origin, race, and religion. [FN177] This provision carries a lot of weight in public discourse and is taken at face value. Color- blindness is a fundamental imperative for the Republic. The Conseil Constitutionnel does not have to deal with origin and ethnicity as suspect categories because they do not surface as definitional criteria in French legislation. Gathering demographic information on race, religion, or ethnicity, even for census or statistical inquiries, is traditionally prohibited. [FN178] The official census uses three categories only: French by birth, French by naturalization, and foreign. [FN179] The children of naturalized immigrants belong in the first category, which reveals nothing about the national origin of those classified under it. [FN180] French is still the only official language. [FN181] Citizenship is still a unitary concept, and justice is still affirmed on individual bases. [FN182]

There are several reasons for this attitude. The most emotionally charged is the memory of the Vichy period, during which individuals experienced the denial of basic rights due to their religious or group affiliation. Second, the acknowledgment of different groups of citizens within the French territory would threaten the very existence of the Republic, which, according to the Constitution, is and must remain a unitary state. A third reason lies in the historical strength of egalitarian slogans. Equality (across social classes rather than ethnicities or nationalities) was the philosophical and political engine behind the French Revolution, and is still perceived as the ideological building block of the nation. Until recently, French diplomats would deny the very existence of minorities in France. [FN183] 
Rooted as it is in the unity of metaphysical reason, modern France is at odds historically with the diverse logics of multiculturalism. The French-Republican model of citizenship differs from the German because the French model is not traditionally centered on ethnicity. It is based, instead, on a shared allegiance to a hard core of civic values, allegedly grounded upon the time- honored Declaration des droits de I'homme et du citoyen, [FN184] observed up to this day with some dark interruptions. Immigrants have relatively easy access to naturalization, and in any case their children are granted citizenship jure soli. With citizenship comes equality, both formally and in the substance of social benefits. The system is equipped with aggressive antidiscrimination laws reinforced by criminal sanctions, [FN185] but it leaves no room for positive action plans. [FN186]

The policy adopted by the Haut Conseil à l'Integration is referred to as creuset français--a gallicism for melting pot. [FN187] Because right- wing politicians have often resorted to multicultural discourse to express essentially xenophobic views, the overt identification of minorities in legislative and administrative policies may be politically unpalatable. [FN188] Anti-discrimination provisions are pervasive in their application. Not even private, nonprofit associations may discriminate on the basis of nationality in selecting the beneficiaries of their charitable activities: material aid, if given, is to be for all those in need. [FN189]

The discussion of poverty in mainstream law journals, reflecting the law and practice of French census-taking, makes no reference to minorities, even though the "neutral" terms étrangers and exclusion are highlighted as special entries in the tables of contents. [FN190] A survey conducted in the year 2000 by the National Observatory of Poverty and Social Exclusion, meant to measure the availability of rights for "populations in difficulty," was intentionally run without any reference to nationality or ethnicity. [FN191] One must read between the lines of the Observatory's report to find an oblique reference to non-French speaking minorities: those who have difficulty reading and writing, the inquiry reveals, have by far the hardest time accessing information on their legal entitlements. At the same time, they are just about the last ones to complain about it. [FN192]

D. ... and Identity-Based Redistribution

Stepping down to the level of municipalities, one may find a different picture: ethnicity and nationality do indeed feature in town and district regulations, taking many forms and occasionally palatable disguises. There is, of course, no possibility of gathering data on residents' origin. However, French statistics allow for distinctions between citizens and foreigners, and decentralized authorities may make use of such categories if needed. The demographics of a city, for instance, are intuitively essential to any sensible strategy of local government, no matter how opposed the mayor may be to multicultural ideals. Identifying given pockets of ethnicity within large and sociologically complex cities is crucial to urban planning. Due to the indisputable fact of late arrival and, more arguably, to socioeconomic discrimination, minority groups are on average less wealthy than local nationals. Urban development, if left to blind market forces, drives minorities together toward low-income areas, where segregation is a probable result. Ghettos are likely targets of racist mobilization as well as conceptual nightmares for assimilation theorists. [FN193] When the stated goal of urban planning is the prevention of ghettos, it may be helpful to distinguish between foreigners and French citizens, and make sure that both groups receive quotas of subsidized housing. [FN194]

The distinction between citizens and foreigners has other applications in local government. When a much higher than average percentage of a school district's student body consists of children of foreigners, the district can be identified as ZEP 
(Zone d'Education Prioritaire) and provided with additional attention. [FN195] The name of the game is always identity-blind assistance to those in need. Yet the redistribution of public resources is essentially channeled along group-based lines.

To be sure, distinctions between citizens and foreigners are still perceived as identityblind in France. [FN196] Given the embracing character of French citizenship law, which allows for generous naturalization of ethnic minorities, citizenship per se escapes the label of suspect category in the framework of equality. It can be put to use in demographic planning, and quite effectively at that, because French citizens are more likely to be of French descent.

The next step for social planners is to attempt a distinction among French citizens. This time it may be harder not to pierce the veil of neutrality. Yet one finds specific social and economic intervention in favor of the category of "French citizens from overseas." [FN197] And as it happens, in the overseas territories of the Republic virtually no one is of exclusively French origin.

The initiatives of the Fonds d'Action Sociale are most explicitly addressed to the protection and advancement of given minorities. [FN198] This governmental institute for the integration of immigrants earmarks some of its funds for intercultural studies and projects related to the cultures of immigrants (mainly African and Asian). [FN199] From the government's viewpoint, funds are distributed to private associations, rather than to a given minority determined to affirm its own collective identity. The unitary character of citizenship and the individual basis of entitlements remain formally unquestioned. [FN200] The fact is, though, that the picture is slowly changing.

According to traditional French politics, the state's commitment to the ideal of fraternité would progressively take care of the socioeconomic marginalization of newcomers. Even in scholarly works most sensitive to multiculturalism in contemporary France, one can find traces of this vision: "[T]he ethnic problem in France is not cultural, linguistic, or political, but mostly socioeconomic." [FN201] The "headscarf problem," which emerged in the late 1980s, has revealed the fragility of this construct.

All over France, Muslim girls began attending school wearing headscarves, raising the specter of Islamic fundamentalism. [FN202] Schoolmasters, occasionally backed up by no less than the Minister of Education, would then keep them out of school for the sake of secularism in education. The country split between outright defenders of republican laicism and fans of postmodern tolerance. At first the Conseil d'État declined the government's request for policy guidelines, leaving the whole matter to the discretion of schoolmasters. [FN203] But since 1996, the Conseil's answer has been consistent: veiled girls must be allowed in the classroom, insofar as their dressing and posture are not provocative or proselytizing. [FN204] The problem, however, is far from being resolved. School teachers, committed by law to secularism in the classroom, are faced with growing demand for religious expression, including suspended attendance throughout the Ramadan period, scarves, and other "ostentatious signs of belonging." [FN205] It is harder and harder for schools to live with the assumption that all children are equal, and that the problems of immigrant peoples can be reduced to an economic dimension. [FN206] Immigrants' demand for cultural affirmation is growing. The definitions of immigrant identities become ever more diverse, at times conflicting, and ever more resilient to assimilation in the name of blind justice. The individual freedoms of religion and expression do not point to viable solutions.

Most importantly, cultural or religious recognition may result in a group-based reallocation of resources. Schools have begun to provide children of immigrants with 
courses about their respective languages and cultures of origin. [FN207] Such school initiatives did not materialize after a grant of enforceable collective rights on the basis of nationality, religion, or ethnicity. The language of positive action was not implicated. Identity-based benefits stem from discretionary use of public resources, often prompted by negotiations between local authorities and representatives of immigrants' associations. [FN208] Not even France can avoid the dilemma of striking ad-hoc balances between individual equality, neutrality, and collective identity.

E. Identity-Based Redistribution at the Crossroads of Welfare and Culture The policies and administrative practices identified in the previous section are the product of mixed concerns for both the cultural identity and the social welfare of marginalized communities. Interestingly, however, "the cultural" and "the social" are two very separate strands in the contemporary legal discourse on minorities. Indeed, they are often conceived of as opposites. As noted earlier, redistributive policies in the French system are not openly oriented toward minorities. Riva Kastoryano explains that "[i]n discourse, 'less' is determined economically, like social handicaps. The state does not take account a priori of the national or religious origin of families but refers to all economically disadvantaged families." [FN209] A clear echo of this discourse can be found at the E.U. level, where the allegedly clean separation between cultural identity and socioeconomic need is used to delimit the competencies of E.U. institutions. [FN210]

The Union's cultural policy, based on E.C. Treaty Article 151, addresses self-identified communities striving for recognition and survival in the face of assimilating pressure. It mainly uses the vocabulary of identity and values. Article 151 is used to explore the desirability of a distinct set of legal tools, meant to allow group members to keep their identity alive, while maintaining their political affiliation with a larger civic constituency. Within this dimension, states' decision-makers discuss the plausibility of such things as allocation of municipal resources for cultural events, allowance of multicultural representation in the media, accommodation of religious preferences with respect to holidays or dress code in the workplace or in schools, protection of language as an expression of values and cohesion, and so on. In the E.C. Treaty, culture is the subject of an article of its own. [FN211] The Commission's Directorate General for Education and Culture deals with matters of "cultural heritage," paying no regard to the socioeconomic marginalization of some of the cultural communities that it identifies and helps. [FN212]

Welfare discourse, on the other hand, pertains to the socioeconomic rehabilitation of recent immigrants, starting from the assumption that, on average, they face greater economic challenges. The terms of reference here are access to instruction, employment, social benefits, housing, and financing. Cultural identity is not a traditional feature of this discourse. Welfare for an underprivileged group can be conceived of as a neutral project, which identifies addressees on the basis of income rather than belonging.

Welfare, as opposed to multicultural policies, is still the most common European response to marginalization. Constitutional history supports this choice. The French Revolution was inspired by motives of economic redistribution. Equality was born to French life out of class conflict, and was then taken to imply, in its Rousseauvian version, the systemic correction of extreme inequality of wealth and power. [FN213] In the constitutional legacy of Continental Europe, there is a strong imperative to intervene in social matters and to reach out, by law, to the economic fringes of society. The Continental focus on social justice makes the recognition of multiple identities seem, in many circles, not just undesirable and politically divisive, but fundamentally unnecessary. Against this background, the American sensitivity to claims of identity 
and recognition is often dismissed as the unfortunate by-product of the shortcomings of the U.S. welfare system. [FN214]

It is according to this set of tenets that culture and welfare come across as totally separate concepts, the former relegated to rather airy matters and cast in non-political discourse, the latter addressing the materiality of redistribution.In practice, as noted, the two spheres are converging. When the experience of economic marginalization overlaps with minority status (as in the overcrowded ghettos of large urban centers in Europe) identity, coinciding with common cultural heritage, is a fundamental variable in the welfare equation. Programs like state-funded religious schools, use of alternative languages in legal or political fora, and subsidized second- language instruction for first- or second-generation immigrants, are at the same time an homage to cultural diversity and also stepping stools for the economic betterment of the excluded. As observed, both the Union and its members engage in action of this hybrid sort. The culture-versus-welfare dichotomy becomes descriptively inaccurate as it fails to account for numerous policies that clearly fall in between. When culture defines and inspires redistributive policies, welfare is no longer identity-blind.

F. Bridging Identity and Welfare in the Union: The Project of Social Inclusion In recent years, the E.U. discourse on poverty has been significantly modified. [FN215] The E.C. Treaty, in its latest version, contemplates the category of "social exclusion." [FN216] In this field, Community institutions have no power of harmonization. State action can be the subject of supranational coordination efforts and incentive measures, but not of substantial scrutiny before the EC]. [FN217] Social exclusion adds much nuance to poverty discourse. [FN218] It recognizes, in the treaty itself, a special dimension of poverty--one coinciding with a social condition of marginalization, and therefore difficult to eradicate. The Union has already indicated that the fight against social exclusion must now be conducted with special attention to phenomena of collective marginalization: "setting appropriate objectives should also involve ... developing priority actions in favour of specific target groups (for example, minorities ...), with Member States choosing amongst those actions according to their particular situations." [FN219] Community guidelines cannot and do not obligate states to identify "suspect categories" in their poverty programs, [FN220] but encourage them to design their social policies with more precise target groups in mind. [FN221]

This discursive development makes group identity not only visible but also directly connected to welfare intervention. Affirmative action in favor of marginalized groups lies exactly in this connection. Awareness of social exclusion as a particularly thorny dimension of poverty is crucial not only in terms of substantive justice, but also for the correct categorization and channeling of many instruments of social intervention, exceeding the scope of equality review before the ECJ. The fight against social exclusion begins with enhanced enforcement of non-discrimination laws at both the national and supranational levels. But it continues, and moves deeper and further, with state policies now unmistakably characterized by awareness of collective identities. The following Part focuses on technical problems of coordination between these two levels of intervention.

\section{POSITIVE ACTION BETWEEN EQUALITY PARADIGMS AND REDISTRIBUTIVE} POLITICS

The opening Part of this Article introduced the argument that the ECJ should not review positive action policies enacted by member states. In the course of Parts III and IV, that argument gained nuance. The form of judicial restraint advocated here does not imply the overall withdrawal of the Court from its settled case law on equality. As observed, the enforcement of nondiscrimination provisions at a supranational, as well as national, level remains a major tool for the social inclusion of marginalized groups in 
Europe. [FN222] *376 The Court, however, should decline to hear a different sort of complaint--that of traditionally non-discriminated majorities, determined to offset positive action policies that a national system, through the complexity of its own politics and through its own constitutional filter, has come to approve. [FN223]

This Part provides technical support for this argument, and illustrates how the Court has been capable of similar forms of judicial restraint in other politically sensitive areas. Furthermore, the several prohibitions against discrimination in the E.C. Treaty may not be an adequate match for the complex theme of positive action. As observed in Part IV, other treaty provisions, addressing the problem of social exclusion, deal more directly with issues of redistribution and are better suited to capture the true nature of affirmative action plans. These provisions, rather than relying on E.U. rights and ECJ enforcement, leave ample room for state autonomy, and open up alternative avenues for the rehabilitation of marginalized collective identities throughout the Union.

This argument needs further elaboration. The coordination of supranational equality paradigms with new, softer tools of social inclusion raises a number of potential problems, ranging from weakened enforcement of individual rights to uncertain legitimacy of Community action. These problems, currently in the spotlight of European debates on constitutionalism, are examined here through the lens of affirmative action, which adds focus and point to the discussion.

\section{A. The Case for Supranational Restraint in the Judicial Review of Positive Action}

In light of the progressive constitutionalization of fundamental rights in the E.U. legal system, some scholars see it as imperative for the Court to take a higher, more activist, profile in human rights judicial review. [FN224] Others encourage the EC] to improve the quality of its discourse in matters of fundamental rights, so as to bolster its credibility and legitimacy on such issues. [FN225] The Court, the argument goes, should actively solicit input from member states to get a better sense of their constitutional traditions in context. The Court should also rely on the comparative work of its own research and documentation center, and make such work available to member states to intensify communication among national actors. [FN226] These arguments aim at bolstering the ECJ's substantive--if not formal--legitimacy and at extending the scope of its human rights scrutiny.

The argument for judicial restraint, elaborated in this Article, is not in conflict with these views. In the present political context, the goal of removing discrimination by means of rights- or equality-based review is far from being achieved. There is no doubt that the Court can still contribute to the social inclusion of marginalized groups by enforcing equality in individual cases. The non-discrimination clauses contained in Community association agreements with certain third countries are still forcing reluctant E.U. members to extend benefits to immigrant labor. [FN227] The equality provisions of the E.C. Treaty, providing the basis for future judicial review of new members' legislation after the imminent round of E.U. enlargement, are likely to prompt similarly meaningful holdings. [FN228] The European Union's heightened commitment to the promotion of fundamental rights requires further enactment of human rights policies in Brussels. [FN229] The ECJ, in turn, must continue to guarantee the non-discriminatory enforcement of individual rights and extend its reach to encompass new social and economic rights as soon as they gain binding supranational force. [FN230] The traditional form of equality review, with the formidable power of its rhetoric, can still do good work for victims of racial, ethnic, or religious bias. 
The ECJ's enforcement of equal and individual rights, however, runs out of pragmatist steam in matters of positive discrimination. When member states, in the sovereign exercise of their redistributive functions, deem it appropriate and legitimate to confer benefits to identity-defined groups, the Court should suspend its supranational scrutiny and respect the regulatory choices of the member states. This course of judicial action would find support in an authoritative line of precedents.

\section{B. Positive Action à la Keck}

There is a fundamental connection between the "economic constitution" of the Union and the general principle of equality. [FN231] To this day, the enforcement of nondiscrimination still uses the language and the framework for judicial review developed by the EC] in economic matters. [FN232] That connection is worthy of further analysis in the specific context of positive action.

To promote the integration of the Common Market over the course of the past three decades, the ECJ has enforced the EEC Treaty's "commerce clause" of Article 30 (now E.C. Treaty Article 28) along the following evolutionary lines. [FN233] With the pathbreaking Dassonville decision, the Court stated clearly that it would not tolerate any form of national regulation discriminating against other member states' goods.

[FN234] As to non-discriminatory regulation formally affecting local and foreign goods in an identical fashion, Dassonville and the later Cassis de Dijon holding outlined the Court's own rule of reason: [FN235] if such regulation had in any way the effect of hindering interstate trade, it would have to be justified in light of "mandatory requirements" of the regulating state. Further, the means for the realization of such interests would have to prove proportionate and necessary, or narrowly tailored, to the regulation's ends. For many years, this test allowed the ECJ to strike down many forms of state regulation as incompatible with the Treaty of Rome. [FN236] Such holdings resulted, to varying degrees, in the disempowerment of local governments. [FN237] The ensuing normative vacuum would at times, but not always, be filled by Community regulation.

By the late 1980s, the Court's proportionality review seemed to have acquired a life of its own, to the point of exceeding its original design. Traders began to show an "increasing tendency ... to invoke Article 30 of the Treaty as a means of challenging any rules whose effect is to limit their commercial freedom even where such rules were not aimed at products from other member States." [FN238] In Quietlynn, for instance, British merchants tried to dismantle the license system imposed upon retailers of sex articles by claiming that the license requirement reduced the volume of sales of imported "goods." [FN239] The Court's review, requiring a judicial reassessment of the very worth of states' regulatory intervention, proved particularly intrusive upon national policies.

At that point, the Court began to show signs of discomfort in the application of its own test. It continued to review the legitimacy of states' goals allegedly justifying their restrictive measures. But, on a few occasions, it dropped the ultimate burden of ideologically charged inquiries into the lap of national courts, by letting the states themselves determine whether the measures in question were proportionate to such goals. [FN240]

Then the judicial discourse changed. In the famous Keck decision, [FN241] a French regulation preventing retailers from selling goods below their actual purchase price was challenged by retailers who argued that the regulation hindered interstate trade by reducing the volume of French sales of imported products. The Court might have, once more, looked for legitimate state interests justifying the prohibition against sales below cost, and applied in full a Cassis analysis. Instead, distancing itself from its own settled 
case law, the Court declined to review the challenged measure. [FN242] The case rested upon a fine distinction: rules relating to the goods themselves (e.g., packaging or labeling requirements) would indeed fall under the Cassis doctrine and require full scrutiny. By contrast, the rule challenged in Keck (no sale below cost) was no more than a neutral "selling arrangement," or modality of sale--allegedly a totally different category of regulatory intervention. Insofar as they were non-discriminatory, statemandated selling arrangements would fall outside the scope of Article 30. In other words, they would not be reviewed at all.

The doctrinal framework of the Keck holding was not watertight. Its theoretical balance was unsteady. The distinction upon which the decision relied was certainly problematic, and has proved difficult to define in later cases. [FN243]

Nonetheless, prominent scholars hailed Keck as a long overdue confinement of Article 30 to its own proper realm: the elimination of all forms of de facto protectionism by state regulation. In the words of Joseph Weiler, Keck indicated a "willingness on the part of the court openly to acknowledge that its judicial doctrines are rooted in a sociopolitical and economic reality that changes with time and which calls for revision even of the most hallowed canons." [FN244] The hallowed canon in need of revision here was the idea that any hindrance whatsoever of interstate trade would create impermissible obstacles to the thorough economic integration of Europe. Any form of state regulation--even a rule relating to selling arrangements--is always cause for trade diversion or contraction. However, the rules in Keck did not offset the principle of non-discrimination of products on the basis of their origin. They applied to imported and local products equally, in law and in fact. National protectionism was certainly not at stake. The Court concluded, therefore, that such rules would be compatible with the logic of the Common Market and properly left them to the regulatory vision of national authorities. The "no hindrance" pillar of economic integration did not crumble. It was relieved of architectural burdens that it no longer needed to carry.

The change advocated in this Article in matters of positive action--an attitude of judicial restraint, in deference to localism--would rest on firmer ground than the Keck retreat, and would bear strong analogies to that judicial move. This change would also prompt the revision (but not the crumbling) of hallowed canons, and relieve the E.U. principle of equality from the burden of local choices that it is not meant to bear. As in Keck, the prohibition against discrimination would stay the same, in the sense that minority groups and each of their members would remain protected from biased pejorative treatment, and would continue to rely on the ultimate guarantee of review by the ECJ. At the same time, the Court would hold back when faced with challenges to national policies, designed to help marginalized minorities, that have already been vetted by state-level constitutional devices.

\section{The Question of Individual Rights}

The Union is faced with demands for a higher degree of consistency in the definition of its core values. All its institutions, and in particular the Court of Justice, are hard pressed to prove their commitment to the rule of law, and to its corollary of equality. [FN245] The EC] must be guided by a comprehensive view of justice, and guarantee that E.U. policies, even when delegated to the member states for implementation, never come to clash with fundamental rights, both equal and individual. In a system based on the rule of law, judicial review is the promise that rights will be enforced. [FN246] The argument for the contraction of the ECJ's scrutiny in matters of affirmative action must therefore grapple with the question of fundamental rights in E.C. law. 
In matters of gender preferences, the ECJ has so far striven to guarantee the individual rights of those outside the privileged group. This has proven to be the stumbling block of such affirmative schemes as the one at the root of the Abrahamsson litigation. The contraction of ECJ review in matters of positive action would imply a net loss in terms of judicial remedies. Mr. Marschall, Mr. Anderson, and Mr. Griesmar--the three men who fell victims to positive action schemes in the Marschall, Abrahamsson, and Griesmar cases respectively--would have more limited recourse to E.C. justice were their complaints directed against racial, religious, or ethnic forms of preferential treatment. To be sure, these complaints would not fall in a legal vacuum. National systems would not cease to provide time-honored mechanisms of review, and positive action would still be confined within whatever boundaries national laws have established. But in the framework of traditional E.U. constitutionalism, the suspension of supranational equality scrutiny in such cases would still pose a doctrinal puzzle. [FN247]

The limited nature of E.C. competencies, as already discussed, provides a way out of, if not a solution to, the puzzle. If identity-based positive action is understood to be a legitimate tool for the national fight against social exclusion, the lack of supranational judicial review follows naturally from the limits of classic European constitutionalism. This conceptual framework does not, of course, resolve the difficult task of drawing the line between individual-rights protection on the one hand, and aid to those collectively excluded on the other. As indicated by the post-Keck line of ECJ cases, distinguishing between the scope of supranational equality and states' redistributive policies may not be easy. But the stakes of positive action are sufficiently high and politically sensitive to require careful reflection on the proper limits of supranationalism. National governments still retain most regulatory powers in social matters. The case-by-case definition of the wavering line separating the hard core of individual rights from the soft periphery of collective entitlements endorsed by political consensus is still best left in states' hands.

\section{Social Inclusion and the New Forms of Governance}

Further tensions within the traditional paradigm of E.U. constitutionalism arise from the new procedural handling of social matters envisaged by the E.C. Treaty. In matters of social policy the Classic Community Method does not entirely apply. A major CCM condition--a theoretically clean and judicially enforceable division of competencies between the European Community and the states--is muddied here. Member states' control over their respective socioeconomic policies is not only limited by the classic logic of free trade, [FN248] or by the straightjacket of macroeconomic targets imposed by monetary union. [FN249] Sovereignty is also softened at the margins by an intrusive set of incentive, coordination, and review mechanisms arranged by Community institutions.

The subject of social exclusion--crucial, as we have seen, to the theory and practice of affirmative action in Europe--partakes of this hybrid form of governance. The E.C. Treaty now extends to the fight against social exclusion a particular technique, the Open Method of Coordination (OMC), applied so far only in limited areas of economic and employment policy. [FN250] The OMC provides a non-binding mechanism for the coordination of member states' policies. The Council sets common objectives, but such objectives are to be reached by means of independently drafted national action plans (NAPs). [FN251] The Commission, in turn, has the role of promoting comparisons among different state practices, and coordinating national action. The Treaty grants formal advisory status to a Social Protection Committee, meant to provide a stable channel of communication between the Commission and member states in social matters. [FN252] Member states still retain a high degree of autonomy and flexibility. [FN253] 
Themes as delicate as the experimentation of formulae for the coexistence of diverse identities and for reaching out to marginalized groups find adequate reception within this structure of governance. However, the OMC leaves no room for immediately countering national policies running astray of the Commission's guidelines. Nor does it provide supranational judicial remedies for those individuals arguably ignored or penalized by state policies. The question is whether the ECJ can maintain the solidity of its institutional role, while keeping a looser supranational grip on the social aspects of E.U. governance. The answer to this question is complex and requires careful articulation.

E. Positive Action, Social Inclusion, and Supranational Rights Enforcement The theme pervading most of the examples above is redistribution of public resources. Redistribution, or distributive justice, is only marginally implicated by justiciable E.C. rights. "Social rights" do exist at a supranational level, but at present they do not define the ultimate content of welfare choices implemented nationally or sub-nationally throughout the Union. [FN254] As explored in Parts III and IV above, the current model combines a core of justiciable E.C. social rights with a set of entitlements that exceed the scope of supranational judicial review. These entitlements, in turn, consist of a combination of social rights granted by national laws and a mix of supranational, state-based, or sub-national policies that do not give rise to judicial claims, and materialize within the realm of political action or discretionary, decentralized redistribution. [FN255]

Against this mixed background, the role for supranational law in welfare matters remains central in both form and substance. In terms of substance, the ECJ can ensure that members of minority groups receive (at least) as good a package of social benefits as anyone else in any given state. Moreover, enforceable E.C. law can guarantee the achievement of minimum common goals throughout the Union, and ensure the justiciability of core social claims. The Union is currently in the process of articulating its social conscience and bringing to the fore the redistributive streak of its economic agenda. [FN256] Justiciable E.C. rights reflect the current degree of consensus that the supranational forum can provide in matters of welfare benefits for workers and citizens in general. [FN257] If, when, and to what extent the package of social rights, as defined in the E.U. Charter, becomes enforceable, the substantive role of the European courts in this respect will be all the more important. [FN258] But it is clear, at present, that this core does not define the upper limits of locally designed social measures.

In terms of form, supranational law can supply necessary procedural guarantees for the implementation of new ways of governance. [FN259] By providing process review on these matters, the European courts can supervise the distribution of responsibilities among states and E.U. institutions as partners in decision-making, with the goal of promoting the democracy and transparency of new governance mechanisms. [FN260] At this level too, the judicial scrutiny of the European courts remains important. [FN261]

For the rest, substantive supranational review must yield to a "heightened reliance on national democratic credentials." [FN262] In a thoughtful commentary, Oliver Gerstenberg highlights the compatibility of the OMC with the logic of a rule-of-lawbased system and with the need to provide a forum for individual dissenters' complaints:

If a State is subject to a critical recommendation for breach of policy guidelines, deliberate non-compliance may rather be a response to the ambiguity of the guidelines themselves and may be re-interpreted as a move in an argumentative game, in which new facts--perceptions of situation, need and interest--are being fed into the rolling 
process of (re-) defining the guidelines themselves. Conversely, dissenters within a non-complying State may draw on the pool of arguments underlying an EU-guideline in order to re- ignite a debate on their Member State's policy orientation--and in doing so contribute to the emergence of a European public sphere. The OMC stresses, on the one hand, the importance of diversity and context- sensitivity at the national level ... and, on the other hand, the importance of ... a search for a common approach .... [FN263]

This view of the OMC might be overly optimistic, given its faith in the outcome of participatory political processes. However, it offers a plausible avenue for diverse legal and political choices in matters of positive action and identity-based redistribution in the Union.

Alternatively, one might conceive of a substantive, rather than merely procedural, juridification of soft governance. Adding "equality" to the conditions that OMC outcomes must satisfy--along the lines of recent scholarly suggestions [FN264]--would once more provide the EC] with Abrahamsson-like review powers. While more in line with traditional constitutionalism, this choice would produce the undesirable effect of limiting the range of states' tools against social exclusion. [FN265] In this light, subjecting the OMC to substantive constraints may stifle, rather than enhance, the democratic credentials of European constitutionalism. [FN266]

\section{CONCLUDING REMARKS}

Identity-based redistribution, as it materializes through positive action schemes, belongs on the list of those welfare devices around which, at present, the Classic Community Method is not likely to yield consensus. [FN267] The widely different perceptions of multiculturalism in the several member states are certain to become even more diverse in the wake of the enlargement of the European Union. [FN268] Given the panoply of current arrangements and the multiplicity of political and scholarly proposals on such matters, national and sub-national governments are bound to diverge significantly in their choices of legal or political tools for rehabilitating marginalized groups. Some will resort to legal entitlements reinforced by judicial protection. Others will boost the political mobilization of minorities without juridifying their claims. [FN269] Others still will devise complex blends of legal and political mechanisms for targeting identity-based marginalization. Along the spectrum of decentralization, some will let municipalities take charge of decision-making in this respect. Others will cling to uniform national policies. Others still will foster transnational solutions. [FN270] The field is clearly one of "politically salient diversity," [FN271] which cannot be reduced to univocal formulae for centralized judicial review. [FN272]

A caveat applies here with vigor. Things might change upon achievement of a further stage of integration, with a bulky set of enforceable E.C. social rights, a thoroughly harmonized immigration policy, and a deeper degree of consensus on the meaning and value of multicultural diversity. With thicker demos and clearer telos, [FN273] the jurisdiction of the European courts might go well beyond the task of setting floor-levels of social protection, and move on to the design of ceilings. At a much different stage of integration, the ECJ might plausibly engage in judicial scrutiny of positive action. At that point, we would have to worry about striking a new balance between localism and decentralization. [FN274] At that point, we might want to converge toward one uniform understanding of social justice, or toward one coherent vision of welfare and equality to be ultimately endorsed and protected by one court. At that point, we might want to focus on how to improve the dialogue between the ECJ and the Union's periphery, or look at federal experiences in other states for inspiration on how to deal with diversity. But that is another story. 
[FNa1]. Associate Professor, Boston University School of Law. Thanks to Hugh Baxter, Kemper Donovan, Bianca Gardella Tedeschi, Oliver Gerstenberg, Duncan Kennedy, Silvio Micali, Frances Miller, Fernanda Nicola, Maureen O'Rourke, Sarah Robinson, Sergiu Troie, and Joseph Weiler for precious feedback on earlier drafts, and to Carsten Kociok, Samuel Lockner, and Erica Smith for insightful research assistance. Comments can be sent to danielac@bu.edu.

[FN1]. See Brief for Appellant, Gratz v. Bollinger, 2002 U.S. Briefs 516 (2002) (No. 02516) (Lexis); Brief for Appellees, Gratz v. Bollinger, 2002 U.S. Briefs 516 (2002) (No. 02-516) (Lexis); Brief for Appellant, Grutter v. Bollinger, 2002 U.S. Briefs 241 (2002) (No. 02-241) (Lexis); Brief for Appellees, Grutter v. Bollinger, 2002 U.S. Briefs 241 (2002) (No. 02-241) (Lexis).

[FN2]. The words "European Economic Community" (EEC), "European Community" (E.C.), and "European Union" (E.U.) do not mean the same thing. The 1957 Treaty of Rome established the EEC TREATY ESTABLISHING THE EUROPEAN ECONOMIC COMMUNITY, Mar. 25, 1957, 298 U.N.T.S. 11 [hereinafter EEC TREATY]. In 1992, Community law underwent radical changes due to what is popularly known as the Treaty of Maastricht. TREATY ON EUROPEAN UNION, Feb. 2, 1992, 1992 O.J. (C 191). The Treaty of Maastricht extensively reformed the Treaty of Rome; the "European Economic Community" became the "European Community" to reflect an expansion of the Community's competency far beyond strictly economic matters. TREATY ESTABLISHING THE EUROPEAN COMMUNITY, Feb. 2, 1992, 1992 O.J. (C 224). With the Maastricht reform, the European Community became the first of three "pillars" of a much more ambitious and far-reaching supranational project, the European Union. The other two pillars, in their current version, CONSOLIDATED VERSIONS OF THE TREATY ON EUROPEAN UNION AND OF THE TREATY ESTABLISHING THE EUROPEAN COMMUNITY, Dec. 24, 2002, 2002 O.J. (C 325) 1 [hereinafter E.U. TREATY], consist, respectively, of "[p]rovisions on a common foreign and security policy," E.U. TREATY, tit. $V$, and "[p]rovisions on police and judicial cooperation in criminal matters," E.U. TREATY, tit. VI. In both pillars, E.U. action relies on intergovernmental cooperation, rather than on the binding, supranational tools of the E.C. Treaty. This Article focuses primarily on the supranational European project contained within the first pillar, as laid out in the E.C. Treaty. The Treaty of Amsterdam, entered into force on May 1, 1999, reorganized the E.C. Treaty, renumbering all its articles. TREATY OF AMSTERDAM AMENDING THE TREATY ON EUROPEAN UNION, THE TREATIES ESTABLISHING THE EUROPEAN COMMUNITIES AND CERTAIN RELATED ACTS, Nov. 10, 1997, 1997 O.J. (C 340) [hereinafter E.C. TREATY]. When citing to the E.C. TREATY, this Article will cite to the provisions as organized by the Treaty of Amsterdam. However, for the sake of clarity, both pre-Amsterdam and post-Amsterdam provisions will be indicated when necessary. The Treaty of Amsterdam also brought about some important substantive changes, one of which (a new Article 13 in the E.C. Treaty, addressing discrimination on grounds of race, ethnicity, religion, and more) is central to the topic of this Article. See E.C. TREATY art. 13. It is still the case, after yet another round of reform, that most of the project of European integration occurs within the E.C. pillar. See TREATY OF NICE AMENDING THE TREATY ON EUROPEAN UNION, THE TREATIES ESTABLISHING THE EUROPEAN COMMUNITIES AND CERTAIN RELATED ACTS, Feb. 26, 2001, 2001 O.J. (C 80) [hereinafter TREATY OF NICE]. The Community is characterized by institutions endowed with the power to enact binding legislation within the range of powers enumerated in the E.C. Treaty. E.C. legislation takes the form of regulations, directives, and decisions--collectively known as "secondary legislation." Both member state governments and their citizens enjoy rights and are subject to duties, enforceable in national courts, stemming from the E.C. Treaty and from secondary legislation. The European Court of Justice, aided to some extent by the Court of First 
Instance, is ultimately in charge of guaranteeing respect for and uniform interpretation of both the E.C. Treaty and secondary E.C. legislation. This system of binding supranational law, based on justiciable rights, enumerated legislative powers, and centralized judicial review is referred to as traditional constitutionalism, or the Classic Community Method (CCM). CCM is distinguished from emerging alternative, softer, non-binding, non-judicially reviewable forms of European governance such as the Open Method of Coordination (OMC). See Joanne Scott \& David M. Trubek, Mind the Gap: Law and New Approaches to Governance in the European Union, 8 EUR. L.J. 1 (2002).

[FN3]. For a clear statement of the difference between affirmative action in the United States and its European counterpart, see Steven M. Teles, Why Is There No Affirmative Action in Britain?, 41 AM. BEHAV. SCIENTIST 1004 (1998). For a discussion of the distinction between equality of result and equality of opportunity, see Sandra Fredman, Combating Racism with Human Rights: The Right to Equality, in DISCRIMINATION AND HUMAN RIGHTS 9, 19-21 (Sandra Fredman ed., 2001).

[FN4]. Due to the practical relevance of the distinction, affirmative and positive action are used as different, not interchangeable, labels in this Article.

[FN5]. The modification of the E.C. Treaty brought about by the new Article 13, see supra note 2, was essential in empowering the Community to legislate on the subjects of racial, ethnic, and religious discrimination. E.C. TREATY art. 13. From its inception to the present day, the Community has enjoyed enumerated powers only, allowing member states to maintain control of whatever is not contained in the E.C. Treaty.

[FN6]. Race and ethnicity are the subjects of Council Directive 2000/43, 2000 O.J. (L 180) 22 [hereinafter Race Directive]. Religion is one of the grounds for discrimination identified by Council Directive 2000/78, 2000 O.J. (L 303) 16 [hereinafter Framework Employment Directive]. (The other grounds covered by this directive--age, disability, and sexual orientation-- exceed the subject of this paper.) The two directives are often referred to as "the equality directives." E.C. directives require implementation by means of state legislation to acquire full force in national legal systems. Directives give member states deadlines for the implementation of legislation. The deadlines set by the Race Directive and the Framework Employment Directive are July 19, 2003 and December 2, 2006, respectively. Member states enjoy some degree of discretion in the choice of legislative means to achieve the goals mandated by E.C. directives. If questions of interpretation or implementation arise before national courts, it is up to the ECJ to provide such courts with interpretive guidelines. The ECJ's rulings on European matters are binding and must be followed by national judges.

[FN7]. This evolution in European positive action--from concern about gender discrimination to concern about discrimination involving race, religion, and ethnicity--is remarkably at odds with the evolution of affirmative action in the United States, where the scrutiny of race-based discrimination came much earlier than its gender-based analogues. However, the European evolution is unsurprising in light of Europe's recent history. The idea of addressing persistent discrimination along racial and ethnic lines had been tainted by the horrors of World War II. More importantly, such subjects did not belong in a trade-based project of integration. Gender, by contrast, was an untainted category and a permissible target of egalitarian activism. Linked as it was to the fundamental goal of equalizing the cost of labor throughout the Community, gender equality could well enjoy firm and visible status. In the 1957 version of the Treaty of Rome, the prohibition against gender discrimination was only second to that against nationals of another member state (or against their goods and services).

[FN8]. See, e.g., Council Decision 2000/750, pmbl., 2000 O.J. (L 303) 23 ("The program should deal with all grounds of discrimination with the exception of sex, which 
is dealt with by specific Community action. Discrimination on different grounds can have similar features and be combated in similar ways. Experience built over many years in combating discrimination on some grounds, including sex, can be used to the benefit of other grounds." (emphasis added)).

[FN9]. This Article aims to isolate the issue of group entitlements from some of its theoretical implications. The overarching debate on the worth and the very possibility of grouping individuals on such bases as gender, ethnicity, or faith exceeds the scope of this Article. For a sharp outline of the "what is a group" debate, see Claus Offe, "Homogeneity" and Constitutional Democracy: Coping with Identity Conflicts through Group Rights, 6 J. POL. PHIL. 113, 125-31 (1998). These lines of categorization, no matter how coarse, biased, and semantically questionable, feature as relevant variables in social equations. They are regularly contemplated in anti-discrimination legislation, and hence color the working hypotheses of legal decision-makers throughout Europe. For this reason only, this Article does not question their meaning, and takes them at face value as icons of identity and belonging.

[FN10]. This critique is entirely internal to the logic of the European Union's legal system. The U.S. debate on the plausibility of a group-sensitive understanding of the Equal Protection Clause, see U.S. Const. amend. XIV, § 1 started a quarter-century ago and still ongoing, is intentionally kept at the margins of the analysis. See Owen M. Fiss, Groups and the Equal Protection Clause, 5 Phil. \& Pub. Aff. 107 (1976); Jack M. Balkin \& Reva B. Siegel, The American Civil Rights Tradition: Anticlassification or Antisubordination? (Yale Law Sch., Pub. Law Working Paper No. 34, 2002), http:// papers.ssrn.com/abstract $=380800$. This Article does not intervene directly in the substantive merits of that debate for two reasons. First, rather than pointing to any given theory of collective justice, it is this Article's aim to argue for enhanced respect of local legal sensibility and experimentation. Second, it is essential to avoid the trap of false comparisons in politically salient legal matters. This Article takes, therefore, a critical approach to the practice of importing into Europe answers to the problems posed by diversity and marginalization developed in the radically different context of U.S. society and law.

[FN11]. This Article highlights the link between the social policy of E.C. Treaty Title XI (as reformed by the Nice treaty) and the positive action provisions in both the Race Directive and the Framework Employment Directive. For arguments suggesting that the Framework Employment Directive, see supra note 6, could have been based not on E.C. Treaty Article 13, but rather on the social provisions of E.C. Treaty Title XI, see Richard Whittle \& Mark Bell, Between Social Policy and Union Citizenship: The Framework Directive on Equal Treatment in Employment, 27 EUR. L. REV. 677 (2002)

[FN12]. See Scott \& Trubek, supra note 2. Based on the Commission's White Paper on governance, see European Governance--A White Paper, $\operatorname{COM}(01) 428$ final at 8, Scott and Trubek describe the Classic Community Method (CCM) as composed of the following basic elements: the Commission's exclusive right of legislative initiative, the legislative powers of the Council of Ministers and European Parliament to act on those initiatives, the uniformity of rules, and the central role for the European Court in guaranteeing respect for the rule of law.

[FN13]. For a recent critique of the modernist tradition in the context of E.U. law, see Ian Ward, Beyond Constitutionalism: The Search for a European Political Imagination, 7 EUR. L.J. 24 (2001).

[FN14]. For an attempt to capture identity-based group rights within a nonconventional liberal rights framework, see WILL KYMLICKA, MULTICULTURAL CITIZENSHIP: A LIBERAL THEORY OF MINORITY RIGHTS (1995). 
[FN15]. See, e.g., Sandra Fredman, Affirmative Action and the European Court of Justice: A Critical Analysis, in SOCIAL LAW AND POLICY IN AN EVOLVING EUROPEAN UNION 171 (Jo Shaw ed., 2000). Fredman offers a reading of equality that renders affirmative action compatible and coherent with fundamental E.C. law canons.

[FN16]. See KYMLICKA, supra note 14.

[FN17]. EEC TREATY art. 119. After the Treaty of Amsterdam, Article 119 became Article 141. See E.C. TREATY art. 141. The presence of a gender-equality provision in the constituent EEC Treaty is one of the many traits that distinguishes the founding document of the European Union from the U.S. Constitution. See Ward Farnsworth, Women Under Reconstruction: The Congressional Understanding, 94 NW. U. L. REV. 1229,1230 (2000) ("[The Fourteenth] Amendment was understood not to disturb the prevailing regime of state laws imposing very substantial legal disabilities on women, particularly married women.").

[FN18]. See Catherine Barnard, The Economic Objectives of Article 119, in SEX EQUALITY LAW IN THE EUROPEAN UNION 321 (Tamara K. Hervey \& David O'Keeffe eds., 1996).

[FN19]. See generally MARY ANN GLENDON, THE TRANSFORMATION OF FAMILY LAW: STATE, LAW, AND FAMILY IN THE UNITED STATES AND WESTERN EUROPE 148-290 (1989).

[FN20]. In 1975, the Council adopted its first equal rights measure, on the subject of equal pay for men and women. See Council Directive 75/117, 1975 O.J. (L 45) 19. A judicial breakthrough came about with Case 43/75, Defrenne v. Sabena, 1976 E.C.R. 455 . With this decision, the ECJ established that the principle of equal pay for equal work would be binding not only upon member states but also, directly, upon private employers. Id. at 481-82 91 . In the same year, the Council adopted Council Directive 76/207, 1976 O.J. (L 39) 40 (specifying the scope of application of the gender equality principle).

[FN21]. See, e.g., Case 177/88, Dekker v. Stichting Vormingscentrum voor Jong Volwassenen, 1990 E.C.R. 1-3941.

[FN22]. The proportionality test for indirect gender discrimination was first articulated with clarity in Case 170/84, Bilka-Kaufhaus GmbH v. von Hartz, 1986 E.C.R. 1607. Bilka-Kaufhaus, a department store whose part-time employees were almost exclusively female, offered preferential pension treatment to full-time employees. The ECJ asked the national court to verify whether discouraging part-time work was a "real need" of Bilka's, and whether Bilka's differential pension scheme was necessary to fulfill that need. Id. at 1631 ? 2 . For a more recent holding on the same point, see Case C-1/95, Hellen Gerster v. Freistaat Bayern, 1997 E.C.R. I-5253. The concept of indirect gender discrimination is now defined by Article 2 of Directive 76/207, as amended. See Council Directive 2002/73, 2002 O.J. (L 269) 15 (amending Council Directive 76/207).

[FN23]. Council Directive 76/207, supra note 20, art. 2(4). Article 2(8) of Council Directive 76/207, as amended by Council Directive 2002/73, supra note 22, incorporates, by reference, the language of E.C. Treaty Article 141(4), contemplating the possibility of positive action for women. Council Directive 2002/73, supra note 22, art. 2(8). E.C. TREATY art. 141.

[FN24]. Council Recommendation 84/635, 1984 O.J. (L 331) 34-35 (on the promotion 
of positive action for women). See also Council Resolution of 12 July 1982, 1982 O.J. (C 186) 3 (approving the general objectives of the new Community Action Programme on the promotion of equal opportunities for women (1982 to 1985)).

[FN25]. Advocate General (AG) F. G. Jacobs, An Introduction to the General Principle of Equality in EC Law, in THE PRINCIPLE OF EQUAL TREATMENT IN EC LAW 1 (Alan Dashwood \& Síofra O'Leary eds., 1997).

[FN26]. Case 222/84, Johnston v. Chief Constable of the Royal Ulster Constabulary, 1986 E.C.R. 1651, 1687 9 38 ("[I]n determining the scope of any [such] derogation ..., the principle of proportionality, one of the general principles of law underlying the community legal order, must be observed.").

[FN27]. Proportionality, now a well-established concept in the jurisprudence of the EC], is a typical feature of German public law. See PAUL CRAIG \& GRAINNE DE BURCA, EU LAW: TEXT, CASES, AND MATERIALS 350 (2d ed. 1998). When proportionality was first enunciated as a legal principle in Europe, it was invoked in the context of policing to curb excessive forms of repression. In the 1980s, it became a form of heightened scrutiny in Germany's equal protection jurisprudence, meant to be applied when the legislation under review drew differences on the basis of such "immutable characteristics" as listed in Article 3(3) of the Basic Law. Art. 3(3) GG (F.R.G.). See Alexander Somek, The Deadweight of Formulae: What Might Have Been the Second Germanization of American Equal Protection Review, 1 U. PA. J. CONST. L. 284, 292 (1998).

[FN28]. See, e.g., Bilka-Kaufhaus, 1986 E.C.R. at 1607.

[FN29]. Case C-450/93, 1995 E.C.R. I-3051.

[FN30]. Underrepresentation existed when women did not make up at least half of the staff in a given pay bracket. See Gesetz zur Gleichstellung von Frau und Mann im öffentlichen Dienst des Landes Bremen (Landesgleichstellungsgesetz) [Bremen Law on Equal Treatment of Men and Women in the Public Service] § 4(5), v. 20.11.1990 (Brem.GBI. S.433), amended by Gesetz v. 3.2.1998 (Brem.GBI. S.25) (F.R.G.).

[FN31]. See Kalanke, 1995 E.C.R. at I-3074 99.

[FN32]. Id. at I-3078 9 24. The EC]'s decisions on positive action have been the subject of extended and thoughtful commentaries. Fredman, supra note 15, provides a comprehensive analysis, with helpful comparisons to the U.S. experience.

[FN33]. Kalanke, 1995 E.C.R. at I-3078 १ 22.

[FN34]. Id. at I-3078 ๆๆ 21-23.

[FN35]. AG Tesauro, in his opinion to the Court, had observed that "in taking the group as such into consideration, positive action moreover marks a transition from the individual vision to the collective vision of equality" Id. at I-3057-58 9 . The Court of Justice is assisted in its adjudication by AGs, whose opinions (simply advisory and not dispositive of the case) are written in the style of an amicus brief. A divergence of views or reasoning between the Court's holding and the AG's opinion usually signals the highly controversial nature of a case.

[FN36]. For criticism of the Kalanke decision, see Sasha Prechal, Case Law, Case C450/93, Kalanke v. Freie Hansestadt Bremen, 1995 E.C.R. I-3051, 33 COMMON MKT. L. REV. 1245, 1259 (1996) (noting the possibility of a fundamental rights conflict 
between the $\mathrm{ECJ}$ and the German Constitutional Court).

[FN37]. Case C-409/95, Hellmut Marschall v. Land Nordrhein-Westfalen, 1997 E.C.R. I6363.

[FN38]. The government of Nordrhein-Westfalen offered the two examples of "length of service and social reasons." Id. at I-6366-67 98 (opinion of AG Jacobs).

[FN39]. See Case C-158/97, Badeck v. Hessische Ministerpräsident, 2000 E.C.R. I1875, I-1891.

[FN40]. On the vagueness and difficult justiciability of saving clauses, see Austin Clayton, Hellmut Marschall v. Land Nordrhein-Westfalen: Has Equal Opportunity Between the Sexes Finally Found a Champion in European Community Law?, 16 B.U. INT'L L.J. 423 (1998).

[FN41]. Neither the Court nor the AG in either of the two cases cite Johnson v. Transportation Agency, 480 U.S. 616 (1987), but they seem to have in mind the argumentative lines of that holding. In Johnson, the U.S. Supreme Court upheld the validity of an affirmative action plan precisely because it represented "a moderate, flexible, case-by-case approach to effecting a gradual improvement in the representation of ... women in the ... work force." Id. at 616-17. The reference to U.S. case law is usually rather explicit in the ECJ's affirmative action holdings. See Kendall Thomas, The Political Economy of Recognition: Affirmative Action Discourse and Constitutional Equality in Germany and the U.S.A., 5 COLUM. J. EUR. L. 329 (1999).

[FN42]. See, e.g., Albertine Veldman, The Lawfulness of Women's Priority Rules in the EC Labor Market, 5 MAASTRICHT J EUR. \& COMP. L. 403, 410 (1998).

[FN43]. See, e.g., Clayton, supra note 40, at 441-47.

[FN44]. See Luisa Antoniolli Deflorian, The Dilemma of Affirmative Actions: A Comparison Between European Community Law and the American Experience, in DEALING WITH INTEGRATION: PERSPECTIVES FROM SEMINARS ON EUROPEAN LAW 1995-1996, at 87 (Iain Cameron \& Alessandro Simoni eds., 1996). See also Thomas, supra note 41 , at $353-56$.

[FN45]. AG Saggio highlights this development in his opinion in Case C- 158/97, Badeck v. Hessische Ministerpräsident, 2000 E.C.R. I-1875, I-1888-89.

[FN46]. In Badeck, strict quotas were not tolerated with regard to results (actual employment); however, the ECJ was prepared to accept measures which imposed a strict quota reserving at least fifty percent of training places for women, and reserving at least fifty percent of all job interviews to female candidates. Id. at I-1927, I-1929. See also Lisa Waddington \& Mark Bell, More Equal Than Others: Distinguishing European Union Equality Directives, 38 COMMON MKT. L. REV. 587, 602-03 (2001).

[FN47]. Badeck, 2000 E.C.R. at I-1915.

[FN48]. Id. at I-1921-22 (summarizing the intervention of the Prime Minister of the Land of Hesse and explaining that, among others, applicants with a record of voluntary service in the army are given priority over women). For a more recent application of the Marschall doctrine, and a clearer illustration of saving clauses, see Case C-476/99, Lommers v. Minister van Landbouw, Natuurbeheer en Visserij, 2002 E.C.R. I-2891 (reserving subsidized child care only to female officials of the Ministry of Agriculture, while allowing male officials to access the same subsidized nurseries only in cases of 
emergency to be determined by the employer, is permissible insofar as male officials who take care of their children by themselves have access to the same nursery places on the same conditions as female officials).

[FN49]. Badeck, 2000 E.C.R. at I-1884.

[FN50]. Ninon Colneric, Making Equality Law More Effective: Lessons From The German Experience, 3 CARDOZO WOMEN'S L.J. 229, 245 (1996). See also Steve Mazurana et al., International Decisions, Badeck, and Abrahamsson v. Fogelqvist, and Schnorbus v. Land Hessen, 96 AM. J. INT'L L. 453, 460 (2002).

[FN51]. In the case of Germany, there seems to be considerable harmony between the prevailing national view on positive action and the ECJ's view as expressed in Marschall. Manfred Zuleeg, Gender Equality and Affirmative Action Under the Law of the European Union, 5 COLUM. J. EUR. L. 319, 328 (1999) (concluding that "[after Marschall,] the ECJ's approach is in harmony with the German constitution promoting factual reinforcement of legal equality for men and women").

[FN52]. Förordningen (1995:936) om vissa anställningar som professor och forskarassistent vilka inrättas i jämställdhetssyfte [Regulation Concerning Certain Professors' and Research Assistants' Posts Created with a View to Promoting Equality], art. 3 (Swed.), translated in Case C-407/98, Abrahamsson v. Fogelqvist, 2000 E.C.R. I-5539, I-5571.

[FN53]. Id.

[FN54]. Id. at I-5546-47.

[FN55]. Id. at I-5574-75 ११ 23-25.

[FN56]. Id. at I-5581-83 ११ 47-55.

[FN57]. The Court explained this point as early as 1986 in Case 170/84, BilkaKaufhaus GmbH v. von Hartz, 1986 E.C.R. 1607, but did not discuss it in Kalanke, Marschall, or Badeck. See Luisa Antoniolli Deflorian, Affirmative Action in the US: the Legal Dimension, in COMBATING RACIAL DISCRIMINATION: AFFIRMATIVE ACTION AS A MODEL FOR EUROPE 81, 94 (Erna Appelt \& Monika Jarosch eds. 2000) (commenting on Kalanke and Marschall, and noting the oddity of using the proportionality test in indirect discrimination cases but not with regard to positive action).

[FN58]. European Comm'n, Commission Welcomes Court Ruling Upholding Swedish Measures To Combat Female Under-representation In Employment (Jun. 6, 2000), http://www.europa.eu.int/comm/employment_social/equ_opp/news/abrahamsson_ en.html.

[FN59]. Abrahamsson, 2000 E.C.R. at I-5585 ๆ 62.

[FN60]. The EC] promoted proportionality to the status of a general principle of Community law in Case 11/70, Internationale Handelgesellschaft mbH v. Einfuhr- und Vorratsstelle für Getreide und Futtermittel, 1970 E.C.R. 1125. The Court has since applied proportionality tests pervasively in its adjudication.

[FN61]. Gráinne De Búrca, The Principle of Proportionality and Its Application in EC Law, 13 Y.B. EUR. L. 111-12 (1993).

[FN62]. See, e.g., Case C-405/98, Konsumentombudsmannen v. Gourmet 
International Products, 2001 E.C.R. I-1795; Case C-145/88, Torfaen Borough Council v. B \& Q plc, 1989 E.C.R. 3851.

[FN63]. For the legislative history of Swedish Regulation 1995:936, see Abrahamsson, 2000 E.C.R. at I-5570. See also Jo Shaw, Gender and the Court of Justice, in THE EUROPEAN COURT OF JUSTICE 87, 142 (Gráinne De Búrca \& Joseph H. H. Weiler eds., 2001) ("[I]n the context of gender ... the bare realities of legal interpretation have tended more often than not to reassert themselves, leaving the highly formal legacy of an equal treatment principle based on notions of comparison rather than structural disadvantage and societally based inequality.").

[FN64]. On the notion of constitutional asymmetry in the European Union, see Fritz W. Scharpf, The European Social Model: Coping with the Challenges of Diversity, $40 \mathrm{~J}$. COMMON MKT. STUD. 645 (2002).

[FN65]. See GEORGE A. BERMANN ET AL., CASES AND MATERIALS ON EUROPEAN UNION LAW 1371-79 (2002).

[FN66]. See E.C. TREATY art. 137, discussed infra Part IV.F.

[FN67]. Case C-366/99, Griesmar v. Ministère de l'Economie, des Finances et de I'Industrie, 2001 E.C.R. I-9383.

[FN68]. In the French legal system, the Conseil d'État is the highest administrative law court.

[FN69]. C. PENSIONS CIV. MILITAIRES DE RETRAITE, art. L12b (Partie Législative) (Fr.), http://www.legifrance.gouv.fr/. For the Code in force at the time of the Griesmar litigation, see Law No. 64-1339 of Dec. 26, 1964, J.O., Dec. 30, 1964 (Fr.).

[FN70]. Code des Pensions, supra note 69.

[FN71]. The preparatory documents are cited in Griesmar, 2001 E.C.R. ๆ 55.

[FN72]. Id. ๆ 51.

[FN73]. Id. ๆ 56-58.

[FN74]. Interestingly, the referring national court did nothing to soften the impact of the ECJ holding upon the French Code when the case was remanded back to it. In July 2002, the Conseil d'Etat allowed Mr. Griesmar to claim the same pension benefits that his female colleagues would have received simply on the grounds that he had had three children during his career, and had ensured their upbringing. Conseil d'Etat, No. 141112, Séance, Jul. 10, 2002 (Fr.), http://www.conseil-etat.fr ("M. Griesmar a assuré la charge de trois enfants"). There was no mention of other relevant facts, hinted at by the ECJ as perhaps necessary to extend the special pension allowance to men. Was Mr. Griesmar primarily taking care of his children? Was his career impacted in any way by parenting? The French court did not inquire into these matters. Currently, following a series of E.C. directives, several member states are in the process of abolishing all forms of gender preferences in the pensionable age for men and women. See BERMANN ET AL., supra note 65, at 1371-72.

[FN75]. For data on this point partially supporting and partially challenging the idea that public employment is beneficial for women, see Janet C. Gornick \& Jerry A. Jacobs, Gender, the Welfare State and Public Employment: A Comparative Study of Seven Industrialized Countries, 63 AM. SOC. REV. 688 (1998). 
[FN76]. For insights on the contradiction between the deregulatory impact of the ECJ's jurisprudence and the lack of regulatory vision and competency for the European institutions, see FRITZ W. SCHARPF, GOVERNING IN EUROPE: EFFECTIVE AND DEMOCRATIC? (1999).

[FN77]. After the Treaty of Amsterdam, Article 141(4) of the E.C. Treaty reads: With a view to ensuring full equality in practice between men and women in working life, the principle of equal treatment shall not prevent any Member State from maintaining or adopting measures providing for specific advantages in order to make it easier for the underrepresented sex to pursue a vocational activity or to prevent or compensate for disadvantages in professional careers.

E.C. TREATY art. 141(4).

[FN78]. See EEC TREATY art. 48; E.C. TREATY art. 39(2).

[FN79]. EEC TREATY art. 7; E.C. TREATY art. 6 (as in effect 1992) (now art. 12).

[FN80]. E.C. TREATY art. 13.

[FN81]. Race Directive, supra note 6 (implementing the principle of equal treatment between persons irrespective of racial or ethnic origin).

[FN82]. Framework Employment Directive, supra note 6.

[FN83]. Id. pmbl. In its preamble, the Directive is framed as a follow-up to the "important body of community law," in particular Council Directive 76/207, supra note 20 , that has rendered gender equality a well established principle.

[FN84]. Framework Employment Directive, supra note 6, art. 7; Race Directive, supra note 6 , art. 5.

[FN85]. According to Waddington \& Bell, supra note 46, at 602 , the language of the equality directives may be less permissive of state action than E.C. Treaty Article 141(4).

[FN86]. The only relevant area in which national legislation is controlling and arguably non-reviewable is clearly singled out in the "Particular Provisions" of the Framework Employment Directive, supra note 6, art. 15 (recruitment of police and school teachers in Northern Ireland can allow for preferential treatment of the underrepresented religious minority).

[FN87]. It is for the sake of uniformity that Council Directive 2002/73, supra note 22, amended Council Directive $76 / 207$, supra note 20 , on gender equality to include a definition of indirect discrimination identical to the one embraced by the new equality directives. See supra note 23.

[FN88]. See Waddington \& Bell, supra note 46, at 602. Cf. Ursula O'Hare, Enhancing European Equality Rights: A New Regional Framework, 8 MAASTRICHT J. EUR. \& COMP. L. 133, 152 (2001).

[FN89]. On the possibility that the Marschall holding may narrow the range of positive action schemes available under Dutch law, see Lilian Gonçalves-Ho Kang You \& Louise Mulder, Positive Action: the Dutch Experience, in COMBATING RACIAL DISCRIMINATION, supra note 57, at 173 . The authors note that keeping the EC] out of positive action for ethnic minorities would have the advantage of preventing Marschall- 
type scrutiny.

[FN90]. That the EC] may soon be tackling group-based allocations of economic and social rights is, according to some, pure science fiction at best, and a dangerous diversion from the ever-challenging chores of basic economic integration at worst. See Pierre Pescatore, Guest Editorial: Nice-Aftermath, 38 COMMON MKT. L. REV. 265, 26768,271 (2001). Others consider ethnicity and religious identity as natural, unavoidable themes for the Court to confront in the near future. See, e.g., Thomas, supra note 41, at 363-64.

[FN91]. Advocates of the individual-rights critique of positive action insist that any given member of a disadvantaged group may not have experienced such disadvantages so as to require positive or affirmative action. Conversely, given members of an advantaged group may have experienced such disadvantages, and their life chances should not be compromised just because they do not belong to a protected category. This critique informs the opinion of AG Tesauro in Case C-450/93, Kalanke v. Freie Hansestadt Bremen, 1995 E.C.R. I-3051, I- 3057-58.

[FN92]. See Antoniolli Deflorian, supra note 57, at 100-01 (noting that affirmative action in the United States was primarily born out of certain political ideologies, so that if there is to be theoretical support for affirmative action as these ideologies shift, it must be based upon a strong legal framework).

[FN93]. The E.U. law principle of subsidiarity is defined in E.C. Treaty Article 5: In areas which do not fall within its exclusive competence, the Community shall take action ... only if and insofar as the objectives of the proposed action cannot be sufficiently achieved by the Member States and can therefore, by reason of the scale or effects of the proposed action, be better achieved by the Community.

E.C. Treaty art. 5. For an analysis of the complexity of this principle in federal or quasifederal legal systems, see George A. Bermann, Taking Subsidiarity Seriously: Federalism in the European Community and the United States, 94 Colum. L. Rev. 332 (1994).

[FN94]. See Takis Tridimas, The Application of the Principle of Equality to Community Measures, in THE PRINCIPLE OF EQUAL TREATMENT IN E.C. LAW, supra note 25, at 214,215 ("[T] does not seek to advance a particular idea of the social good ....").

[FN95]. For an early application of the equality principle based on E.C. Treaty Article 34(2), a prohibition against discrimination "between producers or consumers" in agricultural matters, see Case 114/76, Bela-Muhle Joseph Bergmann KG v. GrowsFarm GmbH \& Co. KG, 1977 E.C.R. 1211.

[FN96]. See Gráinne De Búrca, The Role of Equality in European Community Law, in THE PRINCIPLE OF EQUAL TREATMENT IN E.C. LAW, supra note 25, at 13.

[FN97]. In 1997 the Union established the European Monitoring Centre on Racism and Xenophobia (EUMC) in Vienna. Council Regulation 1035/97, 1997 O.J. (L 151) 1.

[FN98]. See, e.g., Race Directive, supra note 6, art. 3(2) ("This Directive does not cover difference of treatment based on nationality and is without prejudice to provisions and conditions relating to the entry into and residence of third-country nationals and stateless persons on the territory of Member States, and to any treatment which arises from the legal status of the third- country nationals and stateless persons concerned."). Article 3(2) of the Framework Employment Directive, supra note 6 , is virtually identical to the one just quoted. 
[FN99]. The E.C. Treaty amendments introduced by the Treaty of Amsterdam in 1999 have increased remarkably the powers of the Community in this respect. See E.C. TREATY arts. 61-69 (concerning visas, asylum, immigration, and other policies related to free movement of persons).

[FN100]. See Martin Hedemann-Robinson, An Overview of Recent Legal Developments at Community Level in Relation to Third Country Nationals Resident within the European Union, with Particular Reference to the Case Law of the European Court of Justice, 38 COMMON MKT. L. REV. 525, 525 n.1 (2001).

[FN101]. See, e.g., Case C-58/93, Zoubir Yousfi v. Belgian State, 1994 E.C.R. I-1353; Case C-18/90, Office National de l'Emploi v. Bahia Kziber, 1991 E.C.R. I-199 (holding that non-discriminatory treatment of Moroccan workers was required by a cooperation agreement between the EEC and Morocco). See also Case C-192/89, S. Z. Sevince v. Staatssecretaris van Justitie, 1990 E.C.R. I-3461, I-3462 ("grant[ing] a Turkish worker, after a specified period of legal employment in a Member State, access to any paid employment of his choice," based on the EEC-Turkey Association Agreement of 1963, Council Decision 64/732, 1964 O.J. (217) 3685).

[FN102]. See Síofra O'Leary, The Principle of Equal Treatment on Grounds of Nationality in Article 6 EC: A Lucrative Source of Rights for Member State Nationals, in THE PRINCIPLE OF EQUAL TREATMENT IN E.C. LAW, supra note 25, at 105, 108 (referring to Case 197/86, Brown v. Secretary of State for Scotland, 1988 E.C.R. 3205). For other examples, see id. at 120-21.

[FN103]. Case 186/87, Cowan v. Le Trésor Public, 1989 E.C.R. 195. See also O'Leary, supra note 102 , at 113 .

[FN104]. O'Leary, supra note 102, at 108. For other examples, see id. at 120-21.

[FN105]. The awareness of the atrocities of World War II in the international community is powerfully reflected in the Genocide Convention, adopted unanimously by the United Nations General Assembly on December 9, 1948. The Convention defined genocide as certain enumerated acts "committed with intent to destroy, in whole or in part, a national, ethnical, racial or religious group, as such." Convention on the Prevention and Punishment of the Crime of Genocide, Dec. 9, 1948, art. 2, 102 Stat. 3045, 78 U.N.T.S. 277.

[FN106]. KYMLICKA, supra note 14, at 57. Kymlicka explains that when the Polish and Czech governments failed to meet the demands of their German minorities, ostensibly protected by the League of Nations, the Nazis used this failure as a pretext for military intervention. Id. For a discussion of the strong emphasis on individual rights in the drafting stages of the 1948 Universal Declaration of Human Rights, see MARY ANN GLENDON, A WORLD MADE NEW: ELEANOR ROOSEVELT AND THE UNIVERSAL DECLARATION OF HUMAN RIGHTS 39-41, passim (2001).

[FN107]. See J. G. MERRILLS \& A. H. ROBERTSON, HUMAN RIGHTS IN EUROPE: A STUDY OF THE EUROPEAN CONVENTION ON HUMAN RIGHTS 3-4 (2001).

[FN108]. Council of Europe, EUROPEAN CONVENTION FOR THE PROTECTION OF HUMAN RIGHTS AND FUNDAMENTAL FREEDOMS, Nov. 4, 1950, 213 U.N.T.S. 221 [hereinafter ECHR].

[FN109]. See Abdulaziz v. United Kingdom, 94 Eur. Ct. H.R. (ser. A) at 39 q 82 (1985) ("[M]ore favourable treatment [of a minority group member] is not called for by the 
Convention."). The European Court of Human Rights has held that a difference of treatment between groups may be justified in light of legitimate ends if necessary and proportionate. See, e.g., Case "Relating to Certain Aspects of the Laws on the Use of Languages in Education in Belgium," 6 Eur. Ct. H.R. (ser. A) at 34-35 ๆ 10 (1968). But the Court has shown indifference to individual claims based on collective identity and lifestyles. See Buckley v. United Kingdom, 1996-IV Eur. Ct. H.R. 1271 (finding the eviction of a gypsy from her own land due to regulation prohibiting caravan parking to be a non-disproportionate measure justified by reasons of public safety, health, and the rights of others). The dissenting opinion in Buckley argued that the Court had not applied a sufficiently close scrutiny to the U.K. measure. See id. at 1303 . For a critical analysis of these cases, see Fredman, supra note 3, at 30-34.

[FN110]. ECHR, supra note 108, art. 14.

[FN111]. PROTOCOL NO. 12 TO THE CONVENTION FOR THE PROTECTION OF HUMAN RIGHTS AND FUNDAMENTAL FREEDOMS, Nov. 4, 2000, Europ. T.S. No. 177.

[FN112]. Id. pmbl.

[FN113]. COUNCIL OF EUROPE, EXPLANATORY REPORT ON PROTOCOL NO. 12 TO THE CONVENTION FOR THE PROTECTION OF HUMAN RIGHTS AND FUNDAMENTAL

FREEDOMS १ 16 (2000), http://conventions.coe.int/Treaty/en/Reports/Html/177.htm (emphasis added).

[FN114]. On the foundational period of Community law, see J. H. H. Weiler, The Transformation of Europe, 100 YALE L.J. 2403, 2410-31 (1991).

[FN115]. On "the central role for the individual" in the constitutionalization of E.C. law, see Bruno de Witte, Direct Effect, Supremacy, and the Nature of the Legal Order, in THE EVOLUTION OF EU LAW 177, 205 (Paul Craig \& Gráinne de Búrca eds., 1999). Most recently, with the explicit goal of reinforcing the protection of individual rights in E.C. law, the Court of First Instance has significantly expanded the scope of individual standing to challenge Community acts. See Case T-177/01, Jégo-Quéré \& Cie SA v. Commission of the European Communities, 2002 E.C.R. II-2365.

[FN116]. On the German school of ordo-liberalism and its points of departure from traditional laissez-faire, see Barry J. Rodger, Competition Policy, Liberalism and Globalization: A European Perspective, 6 COLUM. J. EUR. L. 289, 293-94 (2000).

[FN117]. See David J. Gerber, The Transformation of European Community Competition Law?, 35 HARV. INT'L L.J. 97 (1994).

[FN118]. The Charter of Fundamental Rights of the European Union, 2000 O.J. (C 364) 1 [hereinafter Charter of Fundamental Rights], was "proclaimed" but not formally adopted by the European Parliament, Council, and Commission in Nice in December 2000. It does not enjoy binding legal force. The ongoing Constitutional Convention on the Future of the European Union, in charge of drafting a new Constitutional Treaty for the Union, is discussing the incorporation of a bill of rights, which mirrors, at least in part, the Charter. For updated information on the status of the convention, see http:// www.europa.eu.int/futurum/index_en.htm (last visited Apr. 15, 2003).

[FN119]. Charter of Fundamental Rights, supra note 118, art. 23. For a puzzled account of the limited scope of Charter Article 23, see O'Hare, supra note 88, at 159.

[FN120]. See Charter of Fundamental Rights, supra note 118, art. 22 ("The Union shall respect cultural, religious and linguistic diversity."). 
[FN121]. This rhetoric is most developed in France. See infra Part IV.C.

[FN122]. See Council Directive 92/50, 1992 O.J. (L 209) 1 [hereinafter Public Service Contracts Directive] (relating to the coordination of procedures for the award of public service contracts).

[FN123]. Interpretative Communication of the Commission on the Community Law Applicable to Public Procurement and the Possibilities for Integrating Social Considerations into Public Procurement, 2001 O.J. (C 333) 27, pt. 1.4.1 [hereinafter Interpretative Communication of the Commission] (emphasis added).

[FN124]. AGREEMENT ON GOVERNMENT PROCUREMENT, Apr. 15, 1994, MARRAKESH AGREEMENT ESTABLISHING THE WORLD TRADE ORGANIZATION, Annex 4B, LEGAL INSTRUMENTS--RESULTS OF THE URUGUAY ROUND vol. 31, 1915 U.N.T.S. 103.

\section{[FN125]. Id.}

[FN126]. Interpretative Communication of the Commission, supra note 123, pt. 1.4.1 n.54. The principle is also embodied in Article 3(2) of the Public Service Contracts Directive, supra note 122 .

[FN127]. The U.S. government took a different course and negotiated a derogation in the Agreement on Government Procurement, whereby twenty percent of contracts are reserved for "small minority businesses." Interpretative Communication of the Commission, supra note 123, pt. 1.4.1 n.51.

[FN128]. The relevance of subnational regions in E.U. governance is one symptom of this phenomenon. E.C. Treaty Article 263 confers advisory status to a "Committee of the Regions," whose democratic credentials have been enhanced recently by the Nice reform. E.C. TREATY art. 263; TREATY OF NICE, supra note 2 art. 2, no. 42 (laying out the amendment to be made to E.C. Treaty Article 263).

[FN129]. EUROMED HERITAGE: REGIONAL PROGRAMME IN SUPPORT OF THE DEVELOPMENT OF EURO-MEDITERRANEAN CULTURAL HERITAGE 8, http://europa.eu.int/comm/external_relations/euromed/euromedheritage-proj_en.pdf (last updated Feb. 23, 2001).

[FN130]. Id.

[FN131]. See KYMLICKA, supra note 14, at 110-11 (arguing that the "benign neglect" of the diversity of minorities by a government in fact condemns the minority cultures to ever-increasing marginalization).

[FN132]. See, e.g., Case C-379/87, Groener v. Minister for Educ., 1989 E.C.R. 3967, 3972 I 23 (Opinion of AG Darmon) (noting that in Ireland, the Irish language is "a repository of and a means of transmitting a common cultural heritage").

[FN133]. Notably, the protection of minorities is mandatory for those states who wish to join the Union in the future, but it is not an explicit requirement for current members. See BRUNO DE WITTE, POLITICS VERSUS LAW IN THE EU'S APPROACH TO ETHNIC MINORITIES 3 EUI Working Paper RSC 2000/4, 2000; Francesco Palermo, The Use of Minority Languages: Recent Developments in EC Law and Judgments of the ECJ, 8 MAASTRICHT J. EUR. \& COMP. L., 299, 301 (2001).

[FN134]. Two cases, Groener, 1989 E.C.R. at 3967, and Case C-274/96, Criminal 
Proceedings Against Bickel and Franz, 1998 E.C.R. I-7637, illustrate this point. In Groener, the Court showed nuanced sensitivity toward the need to keep the Irish language alive among Irish youth. The Court, therefore, approved the requirement of an Irish language test for full time instructors in vocational education. At the end of the day, however, the Groener decision forced the local teaching community to embrace a Dutch national, insofar as she met, one way or another, certain aseptically redefined language requirements. See Nathaniel Bermann, Nationalism Legal and Linguistic: The Teachings of European Jurisprudence, 24 N.Y.U. J. INT'L L. \& POL. 1515, 1567-68 (1992). In the more recent Bickel and Franz decision, the Court did demonstrate deference towards Italy's established policy of granting bilingual service in all administrative and judicial proceedings to its German-speaking minority living in the northern region of South Tyrol, but it also required that the same policy be extended to German-speaking non-residents who happened to travel in that region. The Italian Government argued to no avail that its rules were meant to "recognize the ethnic and cultural identity" of a given minority, and should not be applied to outsiders. Corte cost., 19 giu. 1998, n.213 (Italy). The Court insisted that Austrian and German visitors were to enjoy the same linguistic privilege. Once more, state legislation precisely designed to erect walls around autochthonous groups was deprived of its own building blocks.

[FN135]. The Court has stated emphatically that "the protection of ... a minority may constitute a legitimate aim." Bickel and Franz, 1998 E.C.R. at I- 7659 १ 29.

[FN136]. On the Culture 2000 program, see Palermo, supra note 133, at 300 n.6.

[FN137]. E.C. TREATY art. 151.

[FN138]. Council Directive 77/486, 1977 O.J. (L 199) 32. See BERMANN ET AL., supra note 65 , at 578 .

[FN139]. Council Directive 77/486, supra note 138.

[FN140]. European Parliament and Council Decision 1934/2000, 2000 O.J. (L 232) 1.

[FN141]. European Commission, Press Release, The Celebration of Linguistic Diversity (Feb. 2001), http://culture.coe.fr/AEL2001EYL/eng/diversity.htm.

[FN142]. EUROPEAN MONITORING CTR. ON RACISM AND XENOPHOBIA ET AL., FUNDING MINORITIES AND MULTICULTURALISM IN EUROPE. FUNDERS' ACTIVITIES AGAINST RACISM AND FOR EQUALITY IN DIVERSITY 208-27 (European Found. Ctr. ed., 2001). See also supra note 97.

[FN143]. For general provisions on structural funds, see Council Regulation 1260/1999, 1999 O.J. (L 161) 1.

[FN144]. For this and analogous stories, see the Regional Policy--Inforegio Web site of the European Commission, http://www.europa.eu.int/comm/regional_ policy/projects/stories/index_en.cfm (last visited Apr. 15, 2003).

[FN145]. On the lack of transparency of the work of E.U. agencies, see Michelle Everson, Independent Agencies: Hierarchy Beaters?, 1 EUR. L.J. 180 (1995).

[FN146]. See Case 106/96, United Kingdom v. Commission, 1998 E.C.R. I-2729.

[FN147]. E.C. Treaty Article 230 is the basis for the judicial review of Community acts. E.C. TREATY art. 230. Both the European Court of Justice and the Court of First 
Instance, but not the national courts, can perform this judicial function.

[FN148]. See Miguel Poiares Maduro, Europe's Social Self: "The Sickness Unto Death," in SOCIAL LAW AND POLICY IN AN EVOLVING EUROPEAN UNION, supra note 15, at 325.

[FN149]. The E.C. Treaty contemplates explicitly only the harmonization of indirect taxation. See E.C. TREATY art. 93. Some attempts at coordination of certain forms of direct taxation (especially corporate income taxes) have been based on E.C. TREATY arts. 94, 308. See Tracy A. Kaye, European Tax Harmonization and the Implications for U.S. Tax Policy, 19 B.C. INT'L \& COMP. L. REV. 109, 110-25 (1996).

[FN150]. VIVIEN A. SCHMIDT, THE FUTURES OF EUROPEAN CAPITALISM 51 (2002). On the very different attitudes of the E.U. member states toward welfare, and the reasons why these differences matter, see Fritz W. Scharpf \& Vivien A. Schmidt, Introduction, in 1 WELFARE AND WORK IN THE OPEN ECONOMY: FROM VULNERABILITY TO COMPETITIVENESS 6-11 (Fritz W. Scharpf \& Vivien A. Schmidt eds., 2000) [hereinafter THE OPEN ECONOMY]; Vivien A. Schmidt, Values and Discourse in the Politics of Adjustment, in THE OPEN ECONOMY, supra, at 229-309. See also Vivien A. Schmidt, Does Discourse Matter in the Politics of Welfare State Adjustment?, 35 COMP. POL. STUD. 168 (2002).

[FN151]. See Christopher McCrudden, International and European Norms Regarding National Legal Remedies for Racial Inequality, in DISCRIMINATION AND HUMAN RIGHTS, supra note 3, at 251, 255.

[FN152]. See RIVA KASTORYANO, NEGOTIATING IDENTITIES: STATES AND IMMIGRANTS IN FRANCE AND GERMANY 10 (Barbara Harshav trans., 2002). See also JEAN-PHILIPPE MATHY, FRENCH RESISTANCE: THE FRENCH-AMERICAN CULTURE WARS 142-43 (2000) (outlining the historical development of France's traditional rejection of multiculturalism); Erik Bleich, The French Model: Color-Blind Integration, in COLOR LINES: AFFIRMATIVE ACTION, IMMIGRATION AND CIVIL RIGHTS OPTIONS FOR AMERICA 270 (John D. Skrentny ed., 2001).

[FN153]. See Joseph H. H. Weiler, Eurocracy and Distrust: Some Questions Concerning the Role of the European Court of Justice in the Protection of Fundamental Human Rights within the Legal Order of the European Communities, 61 WASH. L. REV. 1103 (1986).

[FN154]. The theory of neo-functionalism, predicting that the integration of one sector of the economy would "spill over" and force integration in other sectors, is developed in ERNST B. HAAS, THE UNITING OF EUROPE: POLITICAL, SOCIAL, AND ECONOMIC FORCES, 1950-1957, at 291-99 (1958).

[FN155]. Case 4/73, Nold v. Commission, 1974 E.C.R. 491, 507.

[FN156]. Case 11/70, Internationale Handelsgesellschaft mbH v. Einfuhr- und Vorratsstelle für Getreide und Futtermittel, 1970 E.C.R. 1125, 1134 १ 3.

[FN157]. Id. at 1134 9 4 ("The protection of [fundamental] rights, whilst inspired by the constitutional traditions common to the Member States, must be ensured within the framework of the structure and objectives of the Community.").

[FN158]. In matters lacking sufficient "nexus" with Community law, states remain the arbiters of human rights compliance in their systems, within the constraints imposed by Council of Europe membership and other international obligations. On the difficulty 
of distinguishing between sufficient and insufficient nexus cases, see, for example, Case C-368/95, Vereinigte Familiapress Zeitungsverlags- und vertriebs $\mathrm{GmbH}$ v. Heinrich Bauer Verlag, 1997 E.C.R. I-3689. When state acts fall within the sphere of Community law, the EC] is technically in charge of the human rights review of those measures, as well as of Community institutions' acts, and its holdings enjoy the usual degree of supremacy. The constitutional courts of the member states give occasional signals of more or less nuanced dissent from this view.

[FN159]. Charter of Fundamental Rights, supra note 118.

[FN160]. See Koen Lenaerts \& Eddy Eddy De Smijter, A "Bill of Rights" for the European Union, 38 COMMON MKT. L. REV. 273, 280-81 (2001).

[FN161]. BVerfGE [Federal Constitutional Court] 89, 155, 1 C.M.L.R. 57 (1994) (the Maastricht decision). In this remarkable opinion, the German Constitutional Court endorsed the supremacy of E.U. law with some qualifications. In particular, it reserved to its own jurisdiction the task of reviewing whether E.C. legal acts remain within Europe's proper competence limits. See id. at 187-88, 1 C.M.L.R. at 89 श 49. The German Constitutional Court has confirmed its cautious and conditional endorsement of the ECJ's human rights jurisprudence: "The [German] constitutional requirements are satisfied ... if the rulings of the European Court of Justice generally ensure effective protection of fundamental rights ... which is to be regarded as substantially similar to the protection of fundamental rights required unconditionally by the Basic Law ...." BVerfGE 102, 147 (164) (examining the constitutionality of the application of the European Union's common market for bananas in Germany), translated in BERMANN ET AL., supra note 65 , at 322 .

[FN162]. Case C-13/94, P. v. S. and Cornwall County Council, 1996 E.C.R. I-2143, I2165 19. On the significance of turning principles and interests into individual rights, see DUNCAN KENNEDY, A CRITIQUE OF ADJUDICATION 308 (2000).

[FN163]. In the Maastricht Decision, the German Constitutional Court reserved the right to review whether E.C. legal acts remain within proper competence limits. See supra, note 161.

[FN164]. Case C-450/93, Kalanke v. Freie Hansestadt Bremen, 1995 E.C.R. I- 3051, I3059 ๆ 9 (opinion of AG Tesauro).

[FN165]. This Article borrows "suspect categories" from U.S. jurisprudence generically, with no reference to the specific meaning of this expression in U.S. law. For a detailed, updated analysis (and thoughtful critique) of "suspect categories" under U.S. judicial scrutiny, see Suzanne B. Goldberg, Equality Without Tiers, 57 U. MIAMI L. REV. (forthcoming 2003).

[FN166]. MARTHA MINOW, MAKING ALL THE DIFFERENCE: INCLUSION, EXCLUSION AND AMERICAN LAW 20-21 (1990).

[FN167]. In the Netherlands, for instance, since 1994, enterprises with a workforce of thirty-five or more are obliged to register the ethnic origins of their employees. See Gonçalves-Ho Kang You \& Mulder, supra note 89, at 176. A joint European Parliament and Council directive prohibits, in general, the processing of such sensitive data as racial or ethnic origin and religious belief. See Parliament and Council Directive 95/46, art. 8.1, 1995 O.J. (L 281) 31. However, the Directive allows the processing of such data under strict procedural controls in certain exceptional contexts, including "the field of employment law." Id. at art. 8.2(b). 
[FN168]. See Paul Taylor, Positive Action in the United Kingdom, in COMBATING RACIAL DISCRIMINATION, supra note 57 , at 159, 161-62.

[FN169]. See Gonçalves-Ho Kang You \& Mulder, supra note 89, at 176-77.

[FN170]. See Maritta Soininen \& Mark Graham, Positive Action in Sweden: From Central Solutions to Local Responsibility for Combating Ethnic Discrimination, in COMBATING RACIAL DISCRIMINATION, supra note 57, at 183, 183, 196, 199.

[FN171]. On the explicit exception of the Framework Employment Directive, supra note 6 , art. 15, allowing for affirmative action in Northern Ireland, see discussion supra note 86.

[FN172]. For reasons mentioned in Part II, gender is the exceptional ground for positive action measures.

[FN173]. A strong form individual-equality rhetoric is also found in Italy. See, e.g., Corte cost., 6 set. 1995, n.422, Racc. uff. corte cost., 117, 655 (Italy).

[FN174]. The 1949 Basic Law of the Federal Republic of Germany prohibits discrimination on grounds of sex, parentage, race, language, homeland and origin, faith, religious or political opinions, and disability. Art. 3(3) GG (F.R.G.). The prohibition provides prejudiced individuals with personal guarantees, but it is not meant to redress the historical disadvantage of given groups. Conceptually, affirmative action is pitted against the fundamental need of protecting individual equality, and is therefore presumed off-limits on German legal soil even when it might be practically useful. Susanne Baer observes that "the group problem of affirmative action is the central nightmare of German lawyers." Susanne Baer, Equality: The Jurisprudence of the German Constitutional Court, 5 COLUM. J. EUR. L. 249,278 n.179 (1999). For a scholarly argument favoring affirmative action for naturalized immigrants, see WILLIAM A. BARBIERI, ETHICS OF CITIZENSHIP: IMMIGRATION AND GROUP RIGHTS IN GERMANY 168 (1998). Article 3 was amended in 1994 to provide cautious endorsement of affirmative action schemes in favor of women. It now provides that Government should promote the implementation of legal equality of women and men, and work toward the removal of existing disadvantages. Art. 3(2) GG (F.R.G.). See Zuleeg, supra note 51 , at 320 . But it is clear that no such tools exist to correct discrimination in any respect other than gender.

[FN175]. Ethnicity, even after the 1999 reform, see Gesetz zur Reform des Staatsangehörigkeitsrechts, v. 15.7.1999 (BGBI. I S.1618) (F.R.G.), is still at the core of German citizenship law, and justifies the grant of de jure citizenship to Aussiedlers (Eastern and Central Europeans of German origin). Special voting privileges and certain cultural guarantees are conferred to the "historical" ethnic minorities of Danes, Sorbs, and Fresians. See Gilbert Gornig \& Christiane Trüe, Minority Protections in Germany, 6 TILBURG FOREIGN L. REV. 69, 83, 92, 99 (1997). These communities (all endowed with German citizenship) enjoy veritable group rights, i.e., "rights granted with regard to group membership and, primarily, in order to protect the group." Id. at 73. On the reasons why a system may come to recognize group-differentiated rights for ethnic minorities, while at the same time rejecting the paradigm of group rights for immigrants, see KYMLICKA, supra note 14, at 117-20. The active involvement of the State in the funding of religious institutions makes faith a visible trait of the system as well.

[FN176]. See Bleich, supra note 152. Bleich reports on a brief parenthesis of affirmative policies in France in the early 1980s. 'The parenthesis was quickly closed due to the disaggregation of minority groups and due to the self-alienation of the élite 
of French intellectuals following the rise of the Front National.

[FN177]. Const., art. 2 (Fr.) ("La France est une République indivisible, laïque, démocratique et sociale. Elle assure l'égalité devant la loi de tous les citoyens sans distinction d'origine, de race ou de religion.").

[FN178]. To be sure, French laws on immigration have often departed from the principle of neutrality and included elements of ethnic discrimination. See Bleich, supra note 152. But it is not uncommon for immigration laws to espouse very different philosophies than those reflected in the integration policy that states adopt vis-à-vis their own citizens. E.U. law has developed a similar model in designing its external and internal rules of membership: with the introduction of the concept of European Citizenship, "the bestowal of citizenship and rights to citizens of the Member States has been accompanied by processes of exclusion, discrimination and marginalization of long-term resident third-country nationals, immigrants and refugees." Theodora Kostakopoulou, Nested "Old" and "New" Citizenships in the European Union: Bringing Out the Complexity, 5 COLUM. J. EUR. L. 389, 411 (1999). This Article focuses only on internal rules of membership, where differential treatment is unusual and potentially at odds with national equality paradigms.

[FN179]. KASTORYANO, supra note 152, at 23.

[FN180]. A mild relaxation of this model is to be found in the category "French by naturalization," where in recent years it has been possible to take notice of the nationality of origin. See id.

[FN181]. France's ratification of the EUROPEAN CHARTER FOR REGIONAL OR MINORITY LANGUAGES, Nov. 5, 1992, Europ. T.S. No. 148, would have required amending the Constitution, but that amendment is not on the legislative agenda.

[FN182]. YASEMIN NUHO LU SOYSAL, LIMITS OF CITIZENSHIP: MIGRANTS AND POSTNATIONAL MEMBERSHIP IN EUROPE 61 (1994).

[FN183]. As a French delegate to the Commission on Security and Cooperation in Europe stated in 1999, "[a]lthough it has no national minorities on its territory, France [is] conscious of the importance of this question for many participating States." Nathaniel Berman, The International Law of Nationalism: Group Identity and Legal History, in INTERNATIONAL LAW AND ETHNIC CONFLICT 25, 25 (David Wippman ed., 1998). France's reservation to the International Covenant on Civil and Political Rights explains that Article 27 of that Covenant, concerning minority rights, could not apply to the Republic, where everybody enjoyed civil and political rights, and therefore there were no minorities to speak of. See Amaryllis Verhoeven, How Democratic Need European Union Members Be? Some Thoughts After Amsterdam, 23 EUR. L. REV. 217, 232 (1998).

[FN184]. Déclaration des droits de l'homme et du citoyen du 26 août 1789, reprinted in LIBERTES ET DROITS FONDAMENTAUX 41 (Mireille Delmas-Marty \& Claude Lucas de Leyssac eds., 1996).

[FN185]. C. PEN., art. 23 (Fr.). Community law contributes to expanding the scope of the French prohibition against discrimination. Free movement of workers, with no obstacle due to their nationality, demands extension of all social benefits to non-French workers coming from other E.U. states or from third countries that have entered association agreements with the Community.

[FN186]. Only women, as a "group," are the exceptional targets of affirmative 
measures, but always in rather cautious terms. The possibility of granting women a pre-determined amount of representation is still considered unacceptable. The fear of group rights surfaces in the political debate surrounding women's issues. It is commonly argued that, if target mechanisms were allowed for women, one would have to allow quotas for ethnic minorities, homosexuals, etc. See France. Liberté, but not Égalité, ECONOMIST, Feb. 27, 1999, at 48. In the U.K., the Labour Party's attempt to introduce women-only electoral lists received the same response. See Teles, supra note 3 , at 1020 .

[FN187]. See Bleich, supra note 152.

[FN188]. See id.

[FN189]. Trib. adm. Marseille, Jan. 11, 2000, No. 9804408, http://

www.rajf.org/ce/tama9804408. The charitable association in question, l'association Fraternité française, which received funding by the local administration, provided aid only to "citizens."

[FN190]. See, e.g., 12 DROIT SOCIAL 1089 (1999) (table of contents).

[FN191]. See Observatoire national de la pauvreté et de l'exclusion sociale (2000), Le rapport 2000 et "Les travaux" de l'Observatoire national de la pauvreté et de l'exclusion sociale, http:// www.social.gouv.fr/htm/pointsur/onpes/.

[FN192]. Hayet Zeggar, L'accès aux droits des populations en difficulté. Une enquête de l'Observatoire national de la pauvreté et de l'exclusion sociale, 5 DROIT SOCIAL 535, 536 (2001).

[FN193]. In French jargon, "assimilation" was a trendy term until not long ago. This signified the belief that the local melting pot would blend all differences and perhaps nourish, without altering, the notion of French identity. More recently, the term "integration" has become a better label for a system that respects minority identities in many ways. See Bleich, supra note 152 .

[FN194]. Bleich, supra note 152. Such plans may be incompatible with E.C. law, insofar as they are focused on French citizenship and therefore discriminatory against nationals of other E.C. states or against third-country nationals protected by external E.C. agreements. See Case 65/81, Reina v. Landeskreditbank Baden-Württemberg, 1982 E.C.R. 33 (outlawing a system of interest-free loans provided by a German state bank to parents for coverage of childbirth expenses on the condition that at least one spouse be German).

[FN195]. KASTORYANO, supra note 152, at 79.

[FN196]. This is not exactly true, because citizenship spawns its own identity. See, e.g., BENEDICT ANDERSON, IMAGINED COMMUNITIES (Verso 1991) (1983); JOHN BREUILLY, NATIONALISM AND THE STATE (2d ed. 1994); ERNEST GELLNER, NATIONS AND NATIONALISM (1983).

[FN197]. On the policies of the Association nationale pour l'insertion et la promotion des travailleurs originaires d'Outre-mer (ANT), see Bleich, supra note 152.

[FN198]. Fond d'Action Sociale pour les Travailleurs Immigrés et leur Famille. Established in 1958, the FAS was originally meant to support only immigrants, but now reaches out to all disadvantaged groups so as not to stigmatize the immigrants. See Marie-Thérèse Espinasse, A Brief Look at the Development of Urban Policy in France, 
1977 to 1996, in IMMIGRANTS, INTEGRATION AND CITIES: EXPLORING THE LINKS, 91, 96-97 (Org. for Econ. Coop. \& Dev. ed., 1996).

[FN199]. See Erik Bleich, Re-imagined Communities? Education Policies and National Belonging in Britain and France, in THE POLITICS OF BELONGING: MIGRANTS AND MINORITIES IN CONTEMPORARY EUROPE 60, 69 (Andrew Geddes \& Adrian Favell eds., 1999).

[FN200]. See Soysal, supra note 182, at 61.

[FN201]. MATHY, supra note 152, at 142.

[FN202]. For a recent example, see Une affaire de foulard au lycée français d'Alexandrie, LIBERATION (Fr.), Mar. 23, 2001, at 10.

[FN203]. The Conseil d'État only provided very general guidelines. Students' free expression rights could be limited in situations where they infringed on the religious freedom of others, or worked to the detriment of the educational program of the schools. See Judy Scales-Trent, African Women in France: Immigration, Family, and Work, 24 BROOK. J. INT'L L. 705, n.40 and corresponding text (1999).

[FN204]. See, e.g., Conseil d'État, May 20, 1996, Ministry of Education v. Outamghart (Fr.); Conseil d'État, Mar. 10, 1997, Ligue Islamique du Nord, M. et Mme. Chabou et autres, 30 LES PETITES AFFICHES 10 (Fr.) (cited by Scales- Trent, supra note 203).

[FN205]. Nathalie Guibert, L'école fait face à une montée des revendications identitaires des élèves, LE MONDE (Fr.), Apr. 15, 2000, at 12. A law was proposed on Jan. 19, 2000 by Georges Sarre, an MDC [Citizens' Movement] deputy, to the National Assembly, prohibiting such signs in school. See Proposition de loi visant à garantir le respect du principe de laïcité au sein de l'école publique, No. 2096, Assemblée Nationale, Onzième Législature (2000) (Fr.), http://www.assembleenat.fr/propositions/pion2096.asp.

[FN206]. See Guibert, supra note 205 (quoting Hanifa Cherifi, Mediator of national education in the Affaires des Foulard)

[FN207]. See Guibert, supra note 205.

[FN208]. Semi-formal channels of negotiation between local authorities and associations of foreigners have developed since the 1981 liberalization of the French law of associations. See KASTORYANO, supra note 152, at 101.

[FN209]. Id. at 79.

[FN210]. The EC] has held that employment and working conditions, as elements of immigrants' economic integration, could be the object of Commission measures meant to coordinate the policies of the member states; the cultural integration of immigrants, by contrast, exceeded the social field and could not be part of the Commission's initiatives. See Joined Cases 281/, 283-85/ \& 287/85, Germany v. Commission, 1987 E.C.R. 3203, 3204 9 2. The Court was defining the scope of Article 118 in its original version, which allowed the Commission to "promot[e] close cooperation between Member States in the social field." EEC TREATY art. 118. The original Article 118 has been substantially modified as Article 137 of the E.C. Treaty. See E.C. TREATY art. 137; infra Part IV.F.

[FN211]. E.C. TREATY art. 151. 
[FN212]. The Web site of the Directorate General for Education and Culture portrays cultural heritage as a positive asset only. See http://

www.europa.eu.int/comm/culture/activities/cultural_heritage_dev_en.htm (last visited Apr. 16, 2003).

[FN213]. To this day, American scholars notice in Continental systems a conspicuous tendency to use state action to promote social and economic betterment of the excluded. See Cynthia A. Vroom, Equal Protection Versus the Principle of Equality: American and French Views on Equality in the Law, 21 CAP. U. L. REV. 199, 201-02, 205-07 (1992). When studying the French incarnation of the principle of equality, American legal scholars have noticed its predominantly socioeconomic meaning. See id. at 205-07. Observers of the German constitutional experience have made analogous remarks. See Gerald L. Neuman, Equal Protection, "General Equality" and Economic Discrimination from a U.S. Perspective, 5 COLUM. J. EUR. L. 281, 310 (1999).

[FN214]. Mark Tushnet has recently pointed at the need to reconsider the affirmative action debate along the lines of constitutionalized welfare rights--a move traditionally unthinkable on U.S. soil. See MARK TUSHNET, THE RETURN OF THE REPRESSED: GROUPS, SOCIAL WELFARE RIGHTS, AND THE EQUAL PROTECTION CLAUSE (Issues in Legal Scholarship, The Origins and Fate of the Antisubordination Theory, Article 7, 2002), http:// www.bepress.com/ils/iss2/art7.

[FN215]. "Poverty" has been a concern of Community policy since the Paris Summit of the European Council in 1972. On the evolution of E.C. poverty programs and on the application of the OMC to the project of social inclusion, see Maurizio Ferrera et al., Open Coordination Against Poverty: The New EU "Social Inclusion Process," 12 J. EUR. SOC. POL'Y 227 (2002), and Kenneth A. Armstrong, Tackling Social Exclusion Through OMC: Reshaping the Boundaries of EU Governance, in 6 STATE OF THE UNION: LAW, POLITICS AND SOCIETY ch.8 (T. Börzel \& R. Cichowski eds., forthcoming 2003) (on file with Harvard International Law Journal).

[FN216]. E.C. TREATY art. 136. See also E.C. TREATY art. 137.

[FN217]. E.C. Treaty Article 137, as recently modified by the Treaty of Nice, recites: 1. ... [T] he Community shall support and complement the activities of the Member States in the following fields:

...

(j) the combating of social exclusion

...

2. To this end, the Council:

(a) may adopt measures designed to encourage cooperation between Member States through initiatives aimed at improving knowledge, developing exchanges of information and best practices, promoting innovative approaches and evaluating experiences, excluding any harmonisation of the laws and regulations of the Member States ....

TREATY OF NICE, supra note 2, art. 2.

[FN218]. On the new "social inclusion" discourse, "embracing a variety of ways in which people may be denied full participation in society," see Ruth Lister, Strategies for Social Inclusion: Promoting Social Cohesion or Social Justice?, in SOCIAL INCLUSION: POSSIBILITIES AND TENSIONS 37, 38 (Peter Askonas \& Angus Stewart eds., 2000).

[FN219]. Objectives in the Fight Against Poverty and Social Exclusion, 2001 O.J. (C 82) 2, 4-5 [hereinafter Objectives]. 
[FN220]. The guidelines do contain a list of social indicators, encouraging member states to take specific data on aspects of poverty identified as crucial, but the ultimate choice of social indicators in National Action Plans is left to the member states. Id. at 5.

[FN221]. In the Objectives in the Fight against Poverty and Social Exclusion, meant to inspire member states in the development of national action plans, the Committee of Social Protection (an advisory body granted institutional status in E.C. Treaty Article 144 by the recent Nice reform, see TREATY OF NICE, supra note 2, art. 2) identifies the following goal:

3. To help the most vulnerable:

(a) To promote the social integration of women and men at risk of facing persistent poverty, for example because they ... belong to a group experiencing particular integration problems such as those affecting immigrants.

Objectives, supra note 219 , at 7.

[FN222]. As observed in Part III.A, the ECJ's enforcement of non- discrimination clauses in individual cases has entitled minorities to enjoy rights that states' laws would deny them. See supra note 101 .

[FN223]. For examples of such state policies, see supra Part IV.

[FN224]. See Philip Alston \& J. H. H. Weiler, An 'Ever Closer Union' in Need of a Human Rights Policy: The European Union and Human Rights, in THE EU AND HUMAN RIGHTS 3, 19 (Philip Alston ed., 2002) (point 9).

[FN225]. See Thomas de la Mare, Article 177 in Social and Political Context, in THE EVOLUTION OF EU LAW, supra note 115, at 215, 240.

[FN226]. Id. at 240-41.

[FN227]. For a recent example, see Case C-329/97, Ergat v Stadt UIm, 2000 E.C.R. I1487 (concerning residence permits for Turkish workers in Germany).

[FN228]. Cyprus, the Czech Republic, Estonia, Hungary, Latvia, Lithuania, Malta, Poland, the Slovak Republic, and Slovenia (the "acceding countries") are set to join the European Union on May 1, 2004.

[FN229]. See Alston \& Weiler, supra note 224.

[FN230]. On the development of the Charter of Fundamental Rights within the ongoing Constitutional Convention on the Future of Europe, see supra note 118.

\section{[FN231]. See supra Part III.B.}

[FN232]. AG Tesauro has explained this connection in unambiguous terms:

$[T]$ he principle of equal treatment is fundamental not only because it is a cornerstone of contemporary legal systems but also for a more specific reason: Community legislation chiefly concerns economic situations and activities. If, in this field, different rules are laid down for similar situations, the result is not merely inequality before the law, but also, and inevitably, distortions of competition which are absolutely irreconcilable with the fundamental philosophy of the common market. Case C-63/89, Assurances du Crédit v. Council and Commission, 1991 E.C.R. I-1799, I-1829 (Opinion of AG Tesauro). See Tridimas, supra note 94, at 218 ("[I]n Community law, equality is not only a constitutional necessity but also a keystone of integration."). 
[FN233]. For an insightful analysis of this development, see Miguel Poiares Maduro, We The Court: The European Court of Justice and the European Economic Constitution 3587 (1998).

[FN234]. Case 8/74, Procureur du Roi v. Dassonville, 1974 E.C.R. 837.

[FN235]. Case 120/78, Rewe-Zentral AG v. Bundesmonopolverwaltung für Branntwein (Cassis de Dijon), 1979 E.C.R. 649.

[FN236]. Technically, the EC] has no power to strike down state legislation. The EC] only provides referring national courts with a mandatory interpretation of the Treaty or of secondary E.C. legislation. The ECJ's interpretation may be such as to determine the incompatibility of state provisions with E.C. law. In such a case, it is the duty of national courts to suspend the application of state law, or to reinterpret it, if possible, in line with the ECJ's guidelines. It is then up to the state's legislature to repeal all provisions that are incompatible with E.C. law.

[FN237]. On the "political costs of negative integration," see SCHARPF, supra note 76, at 62 .

[FN238]. Joined Cases C-267/91 \& 268/91, Criminal Proceedings against Keck and Mithouard, 1993 E.C.R. I-6097, I-6131 ๆ 14.

[FN239]. Case C-23/89, Quietlynn Ltd. v. Southend Borough Council, 1990 E.C.R. I3059. The Court avoided the application of the usual test by finding that the licensing system did not constitute a quantitative restriction at all. Id. at I-3081.

[FN240]. Starting a famous judicial saga, certain British retailers challenged national rules preventing them from opening their shops on Sunday. See Case C-145/88, Torfaen Borough Council v. B \& Q plc, 1989 E.C.R. 3851. Were such rules narrowly tailored to the goal of arranging for the collective, simultaneous rest of workers, in light of local sociocultural characteristics? In explicit deference to national wisdom, the Court strove not to answer the question. It endorsed sociocultural objectives as plausible justifications, but left the national courts in charge of determining the proportionality of Sunday laws. This ruling caused great uncertainty among British courts. For a similar approach, see Case C-405/98, Konsumentombudsmannen v. Gourmet International Products AG, 2001 E.C.R. I-1795.

[FN241]. Keck, 1993 E.C.R. I-6097.

[FN242]. Id. at I-6131-32 १ๆ 16-18.

[FN243]. See CRAIG \& DE BURCA, supra note 27, at 620-21.

[FN244]. J. H. H. Weiler, The Constitution of the Common Market Place: Text and Context in the Evolution of the Free Movement of Goods, in THE EVOLUTION OF EU LAW, supra note 115 , at 349,370 . See also MADURO, supra note 233 , at 78 ("The Keck decision brought the concept of discrimination back to the heart of Article 30.").

[FN245]. Carol Harlow notes:

A further tenet of the formal rule of law principle is the doctrine of equality before the law. Here we have the kernel of the 'level playing field' of EC legal rights. Equality as a facet of the rule of law legitimates the EC legal order .... Formal equality pays no heed to outcomes.

Carol Harlow, Voices of Difference in a Plural Community, 50 AM. J. COMP. L. 339, 357 (2002). 
[FN246]. See Jason Coppel \& Aidan O'Neill, The European Court of Justice: Taking Rights Seriously?, 12 LEGAL STUD. 227 (1992).

\section{[FN247]. See supra Part II.}

[FN248]. When potentially in conflict with free movement rules, even measures of national welfare pass muster only if narrowly tailored to legitimate goals. The ECJ has recently clarified that the financial integrity of a state's health insurance system may override fundamental market freedoms. See Case C-120/95, Decker v. Caisse de Maladie des Employes Prives, 1998 E.C.R. I-1831. The Court's review, however, is never meant to question the internal redistributive effects of national measures, or the particular vision of collective justice which inspires them.

[FN249]. The main constraints upon states' economic policies are to be found in the Resolution of the European Council on the Stability and Growth Pact, 1997 O.J. (C 236) 1. In addition, E.C. Treaty Article 99(2) provides that the Council adopt a recommendation setting out "broad guidelines of the economic policies of the Member States and of the Community." E.C. TREATY art. 99(2). The Broad Economic Policy Guidelines (BEPGs), while not binding in a classical sense, appear to be a "hard" form of E.U. governance when compared to "softer" OMC versions, such as the social inclusion OMC. See Iain Begg et al., Economic Policy Coordination in the European Union, 183 NAT'L INST. ECON. REV. 66, 69-70 (2003).

[FN250]. On the development of new forms of social governance, see Silvana Sciarra, Social Values and the Multiple Sources of European Social Law, 1 EUR. L.J. 60 (1995). On the decision to extend the OMC to matters of social inclusion, see EXSPRO, Social Exclusion and Social Protection in the European Union: Policy Issues and Proposals for the Future Role of the EU (2001) (prepared by Iain Begg et al.), http:// www.sbu.ac.uk/euroinst/policyreport.pdf.

[FN251]. Member states dutifully articulated such plans for the first time in 2001, and are in the process of preparing their 2003 NAPs.

[FN252]. E.C. Treaty Article 144, in its post-Nice version, attributes to the Social Protection Committee a number of tasks, among which are monitor[ing] the social situation and the development of social protection policies in the Member States and the Community; ... promot[ing] exchanges of information, experience and good practice between Member States and with the Commission. TREATY OF NICE, supra note 2, art. 2.

[FN253]. Oliver Gerstenberg notes:

The OMC is commonly described as a process working in four stages: first, EU ministers agree on policy goals in the policy area concerned; second, the guidelines are translated by member states into national and regional policies with specific targets; third, the ministers agree on benchmarks and indicators in order to measure and to compare best practice within the EU and world-wide; fourth, through evaluation and monitoring, Member States' performance is assessed relative to each other and to their declared goals.

Oliver Gerstenberg, The New Europe: Part of the Problem--or Part of the Solution to the Problem?, 22 OXFORD J. LEGAL STUD. 563, 568-69 (2002).

[FN254]. For an example of secondary legislation setting the floor, but not the ceiling, of social benefits for E.U. citizens, see Council Directive 96/34, annex, pt. I, cl. 2.1, 1996 O.J. (L 145) 4 (both male and female parents of newborns or newly adopted children must be granted at least three months of leave). Other directives mandate the 
application of state-defined social benefits in a nondiscriminatory fashion. See, e.g., Council Directive 86/378, 1986 O.J. (L 225) 40; Council Directive 79/7, 1979 O.J. (L 6) 24.

[FN255]. Identity-based claims to political and social entitlements may be accommodated by veritable group rights, as defined by Offe, supra note 9 . The term "rights" here indicates that members of given minorities can claim, both collectively and individually, a given entitlement on the basis of identity or affiliation, and that courts are supposed to uphold such claims. As we have seen at both the E.U. and state level, softer, decentralized, discretionary mechanisms of resource allocation are preferred. See supra Parts III, IV.

[FN256]. See Maduro, supra note 148, at 325.

[FN257]. According to some, at present, "it would be neither practical, political, nor desirable for the Community to attempt to create a welfare state at EU level, even post-EMU." Catherine Barnard, EC 'Social' Policy, in THE EVOLUTION OF EU LAW, supra note 115 , at 479,509 . In the view of others, it is highly desirable for Europe to develop a set of enforceable, and not merely programmatic, social rights. Because the logic of integration involves, inevitably, redistribution, the Union should take upon itself the responsibility of achieving consensus on basic lines of distributive justice, and translate such lines into individual entitlements for European citizens. See Maduro, supra note 148 .

[FN258]. See supra note 106.

[FN259]. The academic argument for further accountability or juridification of new governance calls for tighter procedural control, and for continued protection of constitutional rights. See Gráinne De Búrca, The Institutional Development of the EU: A Constitutional Analysis, in THE EVOLUTION OF EU LAW, supra note 115, at 55, 7980. Erika Szyszczak points to the need for accountability, transparency, and protection of constitutional rights as ways to shed light on the "dark side" of the new forms of governance. See Erika Szyszczak, The New Paradigm for Social Policy: A Virtuous Circle?, 38 COMMON MKT. L. REV. 1125, 1170 (2001). See also Everson, supra note 145.

[FN260]. For an example of judicial review in analogous matters, see Case T- 461/93, An Taisce and WWF (UK) v. Commission, 1994 E.C.R. II-733, and Case C- 325/94P, An Taisce and WWF (UK) v. Commission, 1996 E.C.R. I-3727, insightfully analyzed by Joanne Scott, Regional Policy: An Evolutionary Perspective, in THE EVOLUTION OF EU LAW, supra note 115 , at 625 .

[FN261]. See Szyszczak, supra note 259.

[FN262]. Gerstenberg, supra note 253, at 570.

[FN263]. Id. at 571. See also Scharpf, supra note 64, at 653-54.

[FN264]. See Gráinne de Búrca, The Constitutional Challenge of New Governance in the European Union 4 (Feb. 27, 2003) (paper presented at the Ctr. for Eur. Stud., Harvard Univ.) (on file with Harvard International Law Journal).

[FN265]. The ECJ's substantive scrutiny of OMC practices on grounds of equality may thwart the development of alternative legal cultures. Martti Koskenniemi, The Effect of Rights on Political Culture, in THE EU AND HUMAN RIGHTS, supra note 224, at 99, 104 , notes that traditional equality "cannot address the sense of injustice that arises ... 
from structural (economic/social) causation or from the sense of belonging to an oppressed minority."

[FN266]. According to Carol Harlow, the increasing juridification of E.U. politics, which seems to many the cure to the democratic deficit of the Union, leads to the perversion of "a juridified society where every relationship is governed by rules and where litigation is all-pervasive," and stifles the possibility of a rich and plural political discourse. Carol Harlow, European Administrative Law and the Global Challenge, in THE EVOLUTION OF EU LAW, supra note 115, at 261, 281.

[FN267]. See David M. Trubek \& James S. Mosher, New Governance, Employment Policy, and the European Social Model, in GOVERNING WORK AND WELFARE IN A NEW ECONOMY: EUROPEAN AND AMERICAN EXPERIMENTS 33, 53 (Jonathan Zeitlin \& David Trubek eds., forthcoming 2003) (on file with the Harvard International Law Journal) (Despite some Europeanization in social policy, most of the final decisions on the future of the welfare state will be taken by national governments.").

[FN268]. For a sense of the problems of ethnic diversity characterizing Central and Eastern Europe and already under close study by E.U. institutions, see the sections entitled "Human rights and the protection of minorities" in the Commission's 2002 Regular Reports on candidate E.U. members. See, e.g., 2002 Regular Report on Bulgaria's Progress Towards Accession, COM(02)700 final at 28-33, http://europa.eu.int/comm/enlargement/report2002/\#report2002.

[FN269]. For an insistence on political mobilization rather than juridification of claims, see Ruud Koopmans \& Paul Statham, Political Claims- Making against Racism and Discrimination in Britain and Germany, in COMPARATIVE PERSPECTIVES ON RACISM 139, 160-61 (Jessika Ter Wal \& Mayel Verkuyten eds., 2000).

[FN270]. See RIVA KASTORYANO, TRANSNATIONAL PARTICIPATION AND CITIZENSHIP: IMMIGRANTS IN THE EUROPEAN UNION (Transnational Communities Working Paper Series, Oxford Univ., Dec. 1998).

[FN271]. Scharpf, supra note 263.

[FN272]. For a "typology of minority incorporation," and analysis of such terms as exclusion, assimilation, integration, and multicultural pluralism, see Theodora Kostakopoulou, "Integrating" Non-EU Migrants in the European Union: Ambivalent Legacies and Mutating Paradigms, 8 COLUM. J. EUR. L. 181, 184-87 (2002).

[FN273]. These terms are used in the non-Volkish, non-organic, but value- driven dimensions conceived by Joseph H.H. Weiler, Does Europe Need a Constitution? Demos, Telos and the German Maastricht Decision, 1 EUR. L.J. 219, 253-56 (1995).

[FN274]. In the United States, according to some supporters of affirmative action, the recipe for an adequate balance between social experimentation at the periphery and centralized judicial review consists of improving and augmenting the input from local actors into the decision making process of the U.S. Supreme Court. See generally Clark D. Cunningham et al., Passing Strict Scrutiny: Using Social Science to Design Affirmative Action Programs, 90 GEO. L.J. 835 (2002). 